\title{
EVALUATION OF PROSPECTIVE HAZARDOUS WASTE TREATMENT TECHNOLOGIES FOR USE IN PROCESSING LOW-LEVEL MIXED WASTES AT ROCKY FLATS
}

\author{
S. C. McGlochlin \\ R. V. Harder \\ R. T. Jensen \\ S. A. Pettis \\ D. K. Roggenthen
}

\section{DO NOT MICROFLLM COVER}

\section{NOEERE ROCKY FLATS}

Rocky Flats Plant

P. O. Box 464

Golden, Colorado 80402-0464 


\section{DISCLAIMER}

This report was prepared as an account of work sponsored by an agency of the United States Government. Neither the United States Government nor any agency Thereof, nor any of their employees, makes any warranty, express or implied, or assumes any legal liability or responsibility for the accuracy, completeness, or usefulness of any information, apparatus, product, or process disclosed, or represents that its use would not infringe privately owned rights. Reference herein to any specific commercial product, process, or service by trade name, trademark, manufacturer, or otherwise does not necessarily constitute or imply its endorsement, recommendation, or favoring by the United States Government or any agency thereof. The views and opinions of authors expressed herein do not necessarily state or reflect those of the United States Government or any agency thereof. 


\section{DISCLAIMER}

Portions of this document may be illegible in electronic image products. Images are produced from the best available original document. 


\section{DISCLAIMER}

This report was prepared as an account of work sponsored by an agency of the United States Government. Neither the United States Government nor any agency thereof, nor any of their employees, makes any warranty, express or implied, or assumes any legal liability or responsibility for the accuracy, completeness, or usefulness of any information, apparatus, product, or process disclosed, or represents that its use would not infringe privately owned rights. Reference herein to any specific commercial product, process, or service by trade name, trademark, manufacturer, or otherwise, does not necessarily constitute or imply its endorsement, recommendation, or favoring by the United States Government or any agency thereof. The views and opinions of authors expressed herein do not necessarily state or reflect those of the United States Government or any agency thereof.

This report has been reproduced directly from the best available copy.

Available to DOE and DOE contractors from the Office of Scientific and Technical Information, P. O. Box 62, Oak Ridge, TN 37831; prices available from (615) $576-8401$, FTS 626-8401.

Available to the public from the National Technical Information Service, United States Department of Commerce, 5285 Port Royal Rd., Springfield, VA 22161.

\section{Price Codes:}

Microfiche:

Printed Copy: 001-025 pages, Code A02

026-050 pages, Code $A 03$

051-075 pages, Code A04

076-100 pages, Code A05

101-125 pages, Code A06 
Printed

RFP-4264

September 18, 1990

UC-721 DEFENSE WASTE

MANAGEMENT

DOE/OSTI-4500 (Rev. 75)

RFP- -4264

DE91 002535

\section{EVALUATION OF PROSPECTIVE HAZARDOUS WASTE TREATMENT TECHNOLOGIES FOR USE IN PROCESSING LOW-LEVEL MIXED WASTES AT ROCKY FLATS}

S. C. McGlochlin

R. V. Harder

R. T. Jensen

S. A. Pettis

D. K. Roggenthen

SUBJECT DESCRIPTORS

Chemical

Fluidized Bed incinerator

Low-Level Mixed Wastes

Physical

Solidification

Thermal

EG\&G ROCKY FLATS, INC.

ROCKY FLATS PLANT

P. O. BOX 464

GOLDEN, COLORADO $80402-0464$

PREPARED UNDER CONTRACT DE-AC04-90DE62349

FOR THE

ALBUQUERQUE OPERATIONS OFFICE

U.S. DEPARTMENT OF ENERGY

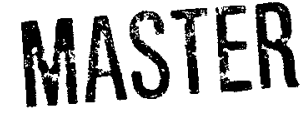




\section{ACKNOWLEDGMENTS}

The authors acknowledge the assistance of E. L. D'Amico and F. P. McMenus for providing characterization data of waste streams proposed as feed for the Fluidized Bed Incinerator and also for clarification of hazardous waste regulations. 


\section{CONTENTS}

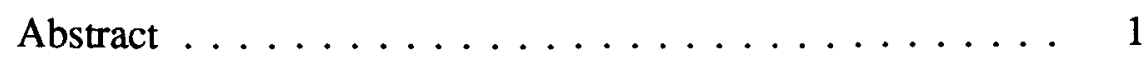

Executive Summary $\ldots \ldots \ldots \ldots \ldots$

Introduction $\ldots \ldots \ldots \ldots \ldots \ldots \ldots \ldots \ldots \ldots \ldots \ldots \ldots \ldots$

Low-Level Mixed Wastes . . . . . . . . . . . . 4

Candidate FBI Wastes $\ldots \ldots \ldots \ldots \ldots$

Non-FBI Mixed Wastes $\ldots \ldots \ldots \ldots$

Evaluation Methodology of Prospective Processes . . . . . 6

Auxiliary Processes ................. 7

Calcining ............... 7

Water Addition ................ 8

Mixing ................. 8

Shredding $\ldots \ldots \ldots \ldots \ldots$

Pelletizing $\ldots \ldots \ldots \ldots \ldots$

Dewatering $\ldots \ldots \ldots \ldots \ldots$

Filtration ............... 9

Thermal Processes $\ldots \ldots \ldots \ldots \ldots \ldots$

Rotary Kiln Incinerator . . . . . . . . . . . 10

Infrared Incinerator $\ldots \ldots \ldots \ldots$

Advanced Electric Reactor . . . . . . . . . . 11

Molten Salts $\ldots \ldots \ldots \ldots \ldots \ldots$

Glass Melter .................. 11

Microwave Melter . . . . . . . . . . . 12 


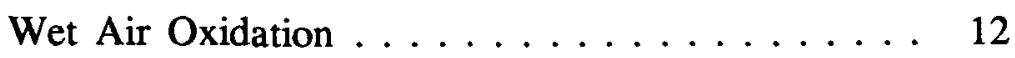

Catalyzed Wet Oxidation . . . . . . . . 12

High-Temperature Wet Oxidation $\ldots \ldots \ldots \ldots 12$

Pyrolytic Decomposition . . . . . . . . . . . 13

High-Temperature Pyrolysis With Oxygen $\ldots \ldots 13$

Fast Rotary Kiln . . . . . . . . . . 13

Cyclone Incinerator $\ldots \ldots \ldots \ldots \ldots \ldots \ldots$

Supercritical Water Oxidation ........... 14

Chemical Processes . . . . . . . . . . . . . 15

Aqueous Phase Alkaline Destruction $\ldots \ldots \ldots 15$

Catalytic Dehalogenation (Dehydrochlorination) . . 15

Ultraviolet Light/Peroxide/Ozone Treatment $\ldots \ldots 16$

Electrochemical Removal of Metal Contaminants . . 16

Biodegradation . . . . . . . . . 17

Physical Processes $\ldots \ldots \ldots \ldots \ldots \ldots \ldots \ldots$

Evaporation $\ldots \ldots \ldots \ldots \ldots \ldots \ldots$

Sonification . . . . . . . . . . . . 19

Crystallization . . . . . . . . . . . . . . 19

Supercritical Carbon Dioxide Extraction $\ldots \ldots .20$

Ion Exchange $\ldots \ldots \ldots \ldots \ldots \ldots \ldots$

Reverse Osmosis . . . . . . . . . . . . 20

Solvent Extraction $\ldots \ldots \ldots \ldots \ldots \ldots \ldots 21$

Fractional Distillation $\ldots \ldots \ldots \ldots \ldots \ldots 22$ 
Air Stripping $\ldots \ldots \ldots \ldots \ldots \ldots \ldots \ldots \ldots$

Activated Carbon Adsorption . . . . . . . . . 23

Steam Stripping $\ldots \ldots \ldots \ldots \ldots \ldots 24$

Immobilization Processes $\ldots \ldots \ldots \ldots \ldots \ldots$

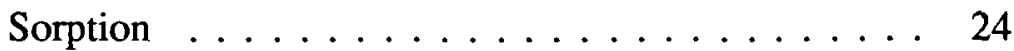

Lime-Fly Ash Pozzolan . . . . . . . . . . . 25

Pozzolanic-Portland Cement . . . . . . . . . . . 25

Thermoplastic Microencapsulation . . . . . . . 25

Macroencapsulation ............ 25

Conclusions $\ldots \ldots \ldots \ldots \ldots \ldots \ldots \ldots \ldots \ldots$

Recommendations ................. 26

References $\ldots \ldots \ldots \ldots \ldots \ldots \ldots \ldots \ldots \ldots$ 


\title{
EVALUATION OF PROSPECTIVE HAZARDOUS WASTE TREATMENT TECHNOLOGIES FOR USE IN PROCESSING LOW-LEVEL MIXED WASTES AT ROCKY FLATS
}

\author{
S. C. McGlochlin, R. V. Harder, R. T. Jensen, S. A. Pettis, and D. K. Roggenthen
}

\begin{abstract}
Several technologies for destroying or decontaminating hazardous wastes were evaluated (during early 1988) as potential processes for treating low-level mixed wastes destined for destruction in the Fluidized Bed Incinerator. The processes that showed promise were retained for further consideration and placed into one (or more) of three categories based on projected availability: short, intermediate, and long-term.
\end{abstract}

Three potential short-term options were identified for managing low-level mixed wastes generated or stored at the Rocky Flats Plant (operated by Rockwell International in 1988). These options are: (1) Continue storing at Rocky Flats, (2) Ship to Nevada Test Site for landfill disposal, or (3) Ship to the Idaho National Engineering Laboratory for incineration in the Waste Experimental Reduction Facility. The third option is preferable because the wastes will be destroyed. Idaho National Engineering Laboratory has received interim status for processing solid and liquid lowlevel mixed wastes. However, low-level mixed wastes will continue to be stored at Rocky Flats until the Department of Energy approval is received to ship to the Nevada Test Site or Idaho National Engineering Laboratory.

Potential intermediate and long-term processes were identified; however, these processes should be combined into complete waste treatment "systems" that may serve as alternatives to the Fluidized Bed Incinerator. Waste treatment systems will be the subject of later work.

\section{EXECUTIVE SUMMARY}

A preliminary evaluation of various hazardous waste treatment technologies was performed to identify potential processes for treating low-level mixed (LLM) wastes stored or generated at the Rocky Flats Plant (RFP). The scope of the study was limited to identifying processes that may be applicable to one or more of the LLM wastes scheduled for destruction in the Fluidized Bed Incinerator (FBI). Additional work will be needed to identify alternative treatment "systems" comprised of several different treatment processes that could be substituted for the FBI.

Low-level mixed wastes contain hazardous constituents (organic and/or inorganic) as defined by the Environmental Protection Agency and transuranic elements in concentrations of less than $100 \mathrm{nCi} / \mathrm{g}$. The evaluations were directed toward treatment of four specific LLM waste streams: dry combustible, wet combustible, plastic, and organic wastes. These wastes are comprised of plutonium-contaminated solids, low-level contaminated liquids, and uranium-contaminated solids.

Liquid LLM wastes, comprised primarily of waste oils, were stored in two tanks. However, waste production during the last few months exceeded the capacity of the tanks, and the oil was placed in drums. These drums, along with drums containing solid LLM wastes, were placed in cargo carriers for temporary storage.

The three primary objectives of the study were to:

1. Identify and evaluate waste treatment processes having potential for treating RFPgenerated LLM wastes.

2. Project availability of those processes having potential for treating LLM wastes:

- Short-term: Operational within one year.

- Intermediate-term: Operational within three to five years.

- Long-term: Operational after five years. 
3. Identify short-term treatment options for managing RFP-generated LLM wastes that may serve as alternatives to the FBI.

The initial list of processes was broad enough to be a representative cross section of available or in-development processes for treating wastes. The following categories of treatment were well represented: auxiliary (e.g., pretreatment), thermal, chemical, physical, and immobilization. None of the processes were evaluated with the intention of supplanting the FBI. In fact, most are capable of acting on a limited number of wastes. Because of the variety of wastes, it is likely that a combined treatment system will be needed to replace the FBI. This system must treat liquids, wet and dry combustibles, and plastics--the same as projected for the FBI. However, this report does not recommend a total treatment system. Such an evaluation will be the subject of later work.

Table 1 lists the process evaluated. Some were not retained for consideration because they lacked potential for treating RFP-generated LLM wastes. Processes retained for consideration include projected availability. Three potential short-term options were identified for managing LLM wastes, allowing time needed to develop an intermediate- or long-term solution. The shortterm options are listed below in order of preference:
1. Transport LLM wastes to the Idaho National Engineering Laboratory (INEL) for incineration in the Waste Experimental Reduction Facility. This option is preferred because incineration is a destructive technology. The facility has received interim status for incinerating solid and liquid LLM wastes. However, at the time of this report, the Department of Energy (DOE) has not granted approval for RFP to begin routine shipments of LLM wastes to INEL.

Further, routine incineration of RFP wastes will not begin until a trial burn is conducted at INEL using 200 gallons of RFP liquid LLM wastes. On January 4, 1989, DOE granted approval for RFP shipment of wastes needed for the test burn. However, a successful trial burn will not automatically lead to shipping LLM wastes to INEL. Although the oil wastes could be incinerated, installation of an off-gas scrubbing system, scheduled for 1989 , is needed to destroy solid LLM wastes because of a higher chloride level. These two combined factors could delay incineration of RFP LLM wastes into 1990.

2. Ship the wastes to the Nevada Test Site for landfill disposal. The wastes must be solidified prior to shipment. Unfortunately, solidification constitutes a treatment, and this

TABLE 1. Waste Treatment Processes Evaluated

\begin{tabular}{|c|c|c|c|c|}
\hline Auxiliary & Thermal & Chemical & Physical & Immobilization \\
\hline $\begin{array}{l}\text { Calcining } \\
\text { Water } \\
\text { Addition } \\
\text { Mixing } \\
\text { Shredding } \\
\text { Pelletizing } \\
\text { Dewatering } \\
\text { Filtration }\end{array}$ & $\begin{array}{l}\text { Rotary Kiln Incinerator (L) } \\
\text { Infrared Incinerator (L) } \\
\text { Molten Salts (L) } \\
\text { Glass Melter (L) } \\
\text { Microwave Melter (L) } \\
\text { Pyrolytic Decomposition } \\
\text { (I,L) } \\
\text { High-Temperature } \\
\quad \text { Pyrolysis (L) } \\
\text { Fast Rotary Kiln (L) } \\
\text { Cyclone Incinerator (I,L) } \\
\text { Supercritical Water Oxidation (L) } \\
\text { Advanced Electric Reactor* } \\
\text { Wet Air Oxidation* } \\
\text { Catalyzed Wet Oxidation* } \\
\text { High-Temperature Wet Oxidation }\end{array}$ & $\begin{array}{l}\text { Aqueous Phase Alkaline (L) } \\
\text { Catalytic Dehalogenation (A) } \\
\text { Biodegradation (L) } \\
\text { Ultraviolet Light/Ozone/Peroxide* } \\
\text { Electrochemical Metal Removal* } \\
*\end{array}$ & $\begin{array}{l}\text { Sonification (A) } \\
\text { Cryogenics (L) } \\
\text { Supercritical } \mathrm{CO}_{2} \text { Extraction } \\
\quad(\mathrm{L}) \\
\text { Solvent Extraction (L) } \\
\text { Fractional Distillation (I,L) } \\
\text { Steam Stripping (A) } \\
\text { Evaporation* } \\
\text { Ion Exchange* } \\
\text { Reverse Osmosis* } \\
\text { Air Stripping* } \\
\text { Activated Carbon Adsorption* }\end{array}$ & $\begin{array}{l}\text { Sorption (S,I,L) } \\
\text { Lime-Fly Ash } \\
\text { Pozzolan (S,I,L) } \\
\text { Pozzolanic- } \\
\text { Portland Cement } \\
\text { (S,I,L) } \\
\text { Thermoplastic } \\
\text { Encapsulation } \\
\text { (S,I,L) } \\
\text { Macroencapsulation } \\
\text { (S,I,L) } \\
\text { Petroset II } \\
\text { Envirostone } \text { R }^{\text {R }, I, L)} \text { (S,I,L) } \\
\text { Portland Cement } \\
\text { (S,I,L) }\end{array}$ \\
\hline $\begin{array}{l}\text { A. Auxiliar } \\
\text { S. Short-te } \\
\text { I. Interme } \\
\text { L. Long-te } \\
\text { * Not reta }\end{array}$ & $\begin{array}{l}\text { availability } \\
\text { e-term availability } \\
\text { vailability } \\
\text { i for further consideration }\end{array}$ & & & \\
\hline
\end{tabular}


activity must be included with those listed in the Part B permit now filed with the Colorado Department of Health. Approval is expected in 1989, and the permit will not be amended to include solidification until the approval is received. In addition to amending the Part B permit, the wastes must comply with the Land Disposal Restrictions effective November 8,1988 . These regulations require landfilled wastes to meet standards for concentrations of hazardous organic compounds in leachates produced by the wastes.

3. Continue to store LLM wastes at RFP. This is the least desirable approach and, at best, only a temporary solution; LLM wastes will not be stored permanently at RFP. If wastes are stored for a significant length of time, additional tanks will be needed to supplement storage provided by two tanks currently filled to capacity. This would permit storing future LLM waste oils in tanks, instead of drums, which are then placed in cargo containers. Solid wastes will continue to be stored in drums.

\section{INTRODUCTION}

The Rocky Flats Plant (RFP), (operated in 1988 by Rockwell International), is a generator oflowlevel mixed (LLM) wastes. The LLM wastes, created during production operations, are contaminated with material identified by the Environmental Protection Agency (EPA) as hazardous substances (listed and/or characteristic) and transuranic elements at concentrations less than $100 \mathrm{nCi} / \mathrm{g}$. The wastes are grouped into three categories: low-level plutoniumcontaminated solids, low-level contaminated liquids, and low-level uranium-contaminated solids. They are comprised of wet and dry combustibles, plastics, and liquid organic wastes.

Currently, LLM wastes are stored in two locations. The first location contains two tanks. Unfortunately, the tanks were filled to capacity during the last few months. This led to storing oil wastes in drums. These drums, along with drums containing solid LLM wastes, are temporarily stored in cargo carriers at RFP. Low-level mixed wastes stored or generated at
RFP will likely be solidified before shipping to an off-site facility for burial (if this option is selected). Solidification constitutes treatment, and subsequently the Part B permit submitted by RFP must be amended to account for this activity. However, no changes will be proposed until the permit receives regulatory approval (expected in 1989). The projected time frame for approval of the permit will affect plans for disposal of LLM wastes at the Nevada Test Site (NTS). The new Land Disposal Restrictions became effective November 8, 1988. These regulations state that concentrations of hazardous organic compounds in leachates from wastes that are landfilled may not exceed the limits listed in Table CCWE of 40 CFR Part 268, Subpart D. Since wastes will be landfilled at NTS, LLM wastes shipped to NTS from RFP must also comply with the Land Disposal Restrictions.

Initially, to avoid accumulating LLM wastes at RFP, bumable wastes were to be destroyed in the Fluidized Bed Incinerator (FBI). However, there has been substantial public opposition to this plan. A lawsuit was filed by the Sierra Club, and an Environmental Assessment is being prepared for the trial burn to satisfy an agreement with the plaintiffs. Colorado Congressman David Skaggs assembled a blue-ribbon panel to review operation of the incinerator. In past years, a number of alternatives to the FBI have been studied. However, in light of recent public concern and to supplement the Environmental Assessment, this study of hazardous waste treatment processes was begun.

This report discusses potential waste treatment processes for destroying, decontaminating, or managing LLM wastes at RFP and presents initial screening results. The three screening objectives were to:

1. Identify waste treatment processes having potential for treating LLM wastes.

2. Project the availability of the treatment processes.

3. Identify short-term (operational within one year) options that may serve as alternatives to the FBI.

None of the promising treatment processes found during the initial screening were proposed as 
substitutes for the FBI; rather, the intent was to identify processes that (when combined with other treatment processes) will provide suitable alternatives to the FBI. For example, different waste forms may require separate unit operations for pretreatment (e.g., filtration), actinide removal (e.g., precipitation), chlorinated hydrocarbon removal (e.g., dechlorination), and sludge disposal (e.g., cementation). Excluding the short-term options, the screening results are for individual treatment processes only.

\section{LOW-LEVEL MIXED WASTES}

An important aspect of identifying technologies for treating wastes is to develop an understanding of waste forms to be processed. The FBI is capable of incinerating both solid and liquid wastes. Furthermore, the designers anticipated burning wastes containing high levels of radioactive contamination and included contamination-control features.

LLM waste is the category of immediate concern; however, future emphasis on hazardous wastes could easily extend to other forms of mixed wastes. This section identifies some physical and chemical characteristics of LLM wastes needing treatment.

\section{Candidate FBI Wastes}

Characterizing FBI waste streams was difficult because of lack of consistent information.

Several sources were reviewed, including an assay of the waste oils from one storage tank, the feed estimates in the test bum plan for the FBI, and waste operations records and reports. However, the records describing characteristics of the wastes are sparse. Furthermore, a major effort to reduce output of hazardous wastes on plantsite is under way, and the volumes of wastes generated have not remained constant.

\section{Categories}

There are three types of LLM wastes proposed as feed material for the FBI: low-level plutonium- contaminated solids, low-level contaminated liquids, and low-level uranium-contaminated solids. Solids are comprised of wet and dry combustibles and plastics. Wet or dry combustibles include items such as paper, cloth, wood, and less than $50 \%$ plastic. Wet combustibles must be drained to prevent the accumulation of free liquids in the storage containers. Plastic wastes are defined as Teflon, ${ }^{\mathrm{R}}$ PVC sheeting, supplied air suits, and other plastics. The liquids are comprised of oils and organic solvents. These wastes are primarily machine oils, but include water-soluble oils such as Trimsol. ${ }^{\mathrm{R}}$ Freon-TF${ }^{\mathrm{R}}$, trichloroethane, and carbon tetrachloride account for most of the hazardous solvents in the organic wastes.

Currently, efforts are being directed toward reducing generation of wastes and also finding appropriate substitutes for halogenated solvents. These efforts have proven successful. The production of liquid LLM wastes has been reduced by approximately half. The generation of these wastes will be further reduced as waste minimization efforts proceed.

The continued storage of these wastes generates significant concern. If wastes in storage could be eliminated, the suddenly expanded capacity would be sufficient to store the yearly LLM waste production until an alternative treatment could be found. This problem becomes notable when considering the waste oil storage tanks. At current production levels, the tanks have several years' storage capacity. Therefore, eliminating the liquid wastes stored in the tanks becomes a high priority.

\section{Oil Tank Analyses}

Samples of waste oils from the two tanks were evaluated. Oil in the first tank contained approximately 5\% water while the second tank contained approximately $7 \%$ water. Oil samples from the first tank were also more flammable and lighter in color.

Oil samples from the second tank were collected and analyzed by the RFP analytical laboratory. Assuming the samples are representative of the oils in both tanks, the following results are 
indicative of the organic and inorganic constituents:

The oil has a pH of 5.9, specific gravity (at $25^{\circ} \mathrm{C}$ ) of 0.8869 , and viscosity (at $100^{\circ} \mathrm{F}$ ) of $210.4 \pm 1.4$ SUS. The heat content is $22,168.5$ $\pm 1,872.8 \mathrm{Btu} / \mathrm{lb}$. The total chloride content is 0.224 wt \% (2240 ppm). Total alpha, uranium, and plutonium content are $(5.5 \pm 0.4) \times 10^{4},(4.6$ $\pm 0.7) \times 10^{4}$, and $\left(1.0 \pm 0.1 \times 10^{4}, \mathrm{pCi} / \ell\right.$, respectively. Water and ash content are 6.5 $\pm 1 \%$ and $1.6 \%$, respectively. Freon- $\mathrm{TF}^{\mathrm{R}}$ concentration is $154 \mathrm{ppb}$.

The metal ion concentrations for the oil are shown in Table 2.

Assays for hazardous semi-volatile compounds showed no concentrations exceeding detectable limits. The concentrations for Hazardous Substance List (HSL) volatile organic compounds are shown in Table 3.

\section{Trial Burn Plan}

During preparation of the trial burn plan, Roy $F$. Weston, Inc. developed an estimate for the composition of the FBI liquid wastes. All of the values were based on historic information. Where specific information was available, actual

TABLE 2. Metal Ion Concentrations From Oil Storage Tank

$\begin{array}{lc}\text { Analyte } & \begin{array}{c}\text { Concentration } \\ \text { (ppm) }\end{array} \\ \text { Arsenic } & 0.02 \\ \text { Beryllium } & 6.2 \\ \text { Cadmium } & 0.2 \\ \text { Mercury } & 0.2 \\ \text { Potassium } & 305.0 \\ \text { Lead } & 92.0 \\ \text { Aluminum } & 25.85 \\ \text { Barium } & 10.68 \\ \text { Calcium } & 230.0 \\ \text { Cobalt } & 1.21 \\ \text { Chromium } & 5.67 \\ \text { Copper } & 5.8 \\ \text { lron } & 81.6 \\ \text { Magnesium } & 57.4 \\ \text { Sodium } & 692.22 \\ \text { Nickel } & 4.1 \\ \text { Strontium } & 1.1 \\ \text { Zinc } & 69.55\end{array}$

TABLE 3. HSL Volatile Organic Compound Concentrations From Oil Storage Tank

\begin{tabular}{lr}
\multicolumn{1}{c}{ Analyte } & $\begin{array}{r}\text { Concentration } \\
\text { (ppb) }\end{array}$ \\
1,1-Dichloroethane & 24 \\
Chloroform & 40 \\
1,1,1-Trichloroethane & 1,372 \\
Carbon Tetrachloride & 200 \\
Trichloroethane & 30 \\
1,1,2,2-Tetrachloroethane & 10 \\
Toluene & 1,044 \\
Ethylbenzene & 424
\end{tabular}

TABLE 4. Estimated Composition of Liquid LLM Wastes Scheduled for Destruction in the FBI

\begin{tabular}{lr} 
& $\begin{array}{r}\text { Total } \\
\text { Waste Material }\end{array}$ \\
\cline { 2 - 2 } Oils - Mineral, Used, etc. & 92.96 \\
Dioctylphthalate & 2.12 \\
Mineral Spirits & 1.91 \\
Ethanol & 1.33 \\
Solvents - Flammable, etc. & 1.02 \\
Xylene \& toluene & 0.17 \\
Dibutyl N,N diethylcarbamyl & 0.13 \\
$\quad$ Phosphonate/Triisooctylamine & \\
Paints & 0.10 \\
Chloroform & 0.08 \\
I2, SO 2 Pyridine in Methoxyethanol & 0.05 \\
Carbon Tetrachloride & 0.03 \\
2-Ethoxyethanol \& Phosphorous & 0.01 \\
Unknown & 0.09 \\
Total & 100.00
\end{tabular}

400 litre of styrene is also scheduled for incineration

compounds were identified; otherwise, the general category was listed. This information is shown in Table 4.

\section{Non-FBI Mixed Wastes}

Burnable LLM wastes account for only a small percentage of RFP LLM wastes. The major sources are nitrate-salt and pond-sludge cement mixtures. Currently, there are no treatment processes (including the FBI) that could be licensed for destroying these types of wastes. For the short term, it appears they can be stored temporarily at RFP for eventual shipment to an off-site storage facility. However, an acceptable long-term treatment technology eligible for 
receiving a permit must be developed. The ideal long-term technology would have capability to treat or destroy all types of LLM waste.

As seen in Figure 1, low-level burnable wastes are only a small percentage of all burnable RFP wastes. At this time, the other types of hazardous wastes, TRU-mixed and nonradioactive hazardous, can be shipped to off-site treatment or storage facilities. Any system chosen to replace the FBI should be capable of destroying these larger segments of burnable wastes. In the future, new regulations could easily dictate that all liquid hazardous wastes be treated on site.

\section{EVALUATION METHODOLOGY OF PROSPECTIVE PROCESSES}

Numerous prospective waste treatment processes were evaluated for treating hazardous and/or radioactive wastes. This section discusses the methodology used to critique the various methods with objectives to:

1. Determine which prospective waste treatment processes have potential for treating RFPgenerated liquid or solid LLM wastes. A process lacking sufficient potential was rejected, while a process showing promise was retained for further consideration.

2. Project availability of those prospective treatment processes retained for further consideration (Objective 1), using the following categories:
- Short-term availability: These treatment processes could be operational within one year. This eliminates all processes currently being developed. Any shortterm treatment process selected must be readily available from a vendor or use existing technology (e.g., land disposal).

- Intermediate-term availability: These treatment processes could be operational within three to five years. This time frame permits some development activities.

- Long-term availability: These treatment processes would be available after five years. This permits substantial time for developing processes to treat or destroy LLM wastes. Because there is no time limit, consideration may be given to waste treatment processes currently in early development stages.

3. Define potential short-term options for managing LLM wastes scheduled for destruction in the FBI.

The evaluations had two goals. The first was to determine whether the prospective process had a reasonable potential for treating FBI LLM wastes. It is not anticipated that one treatment process can totally substitute for the FBI. Another incineration process may be capable of treating all forms of LLM wastes; however, it is expected that several, if not all, incineration processes will face the same obstacles as the FBI. This does not preclude retaining incineration as a viable technology. Improvements to incineration

FIGURE 1. Annual Burnable Waste Generation at the Rocky Flats Plant

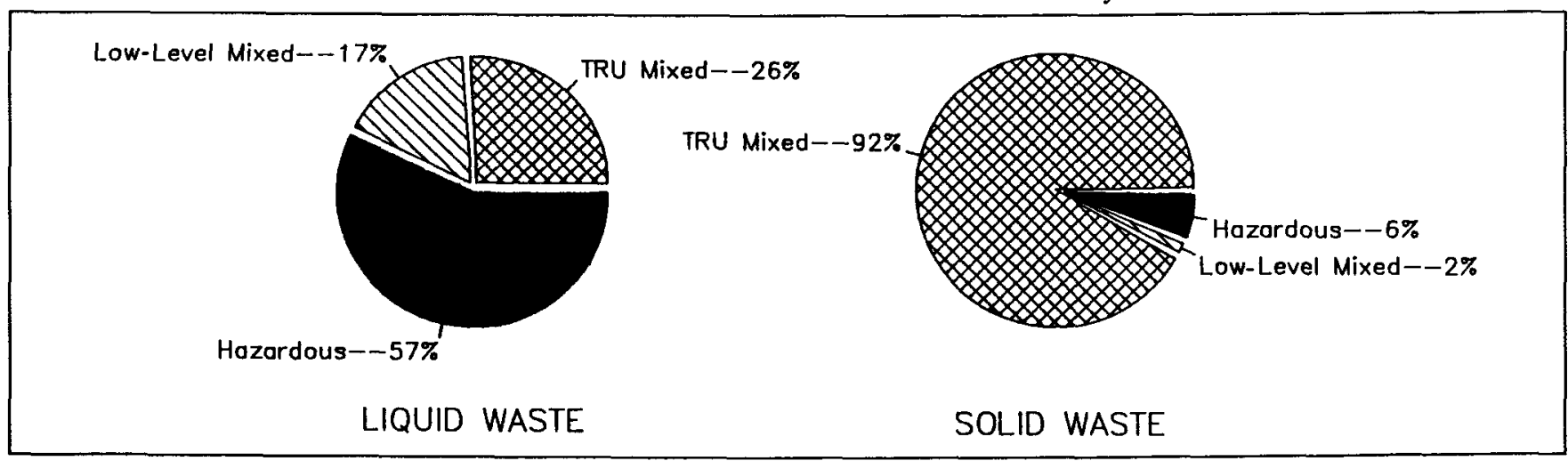


processes have allowed other sites to use incineration successfully. Thus, the purpose for the evaluation was to identify different processes that could be combined into complete treatment systems to serve as alternatives to the FBI.

A treatment system would be capable of treating liquid and solid wastes, wet and dry combustibles, and plastics.

Once a process showed potential, the second goal was to estimate when it would be available. The list (Table 1) of prospective waste treatment processes, although not comprehensive, is a representative cross section of technologies that may be appropriate. However, this does not preclude the possibility that better candidates may later be identified or developed. Sources used to identify and evaluate the processes included professional experience, the literature, and discussions with vendors. Figure 2 displays the steps used during the decision process for Objectives 1 and 2 .

Five waste treatment categories were evaluated: auxiliary, thermal, chemical, physical, and immobilization.

\section{AUXILIARY PROCESSES}

Auxiliary technologies condition (e.g., pretreat) wastes to enhance the efficiency of a waste treatment process. The auxiliary processes evaluated were: calcining, water addition, mixing, shredding, pelletizing, dewatering, and filtration.

\section{Calcining \\ Process Description}

A calciner dries and oxidizes liquids and slurries. The calcine process requires a feed system (e.g., pumps and spray nozzles) furnace, off-gas system, and process control instrumentation. Solids may require some shredding prior to calcining, to shorten residence time inside the furnace. The walls in a calciner furnace are heated to approximately $800^{\circ} \mathrm{C}$. The furnace may be a spray calciner, a rotary-kiln calciner, or a fluidized-bed calciner. The spray calciner furnace uses either an induction or resistance-type heater. The rotary-kiln furnace, developed in France, is an

FIGURE 2. Method for Evaluating Waste Treatment Processes

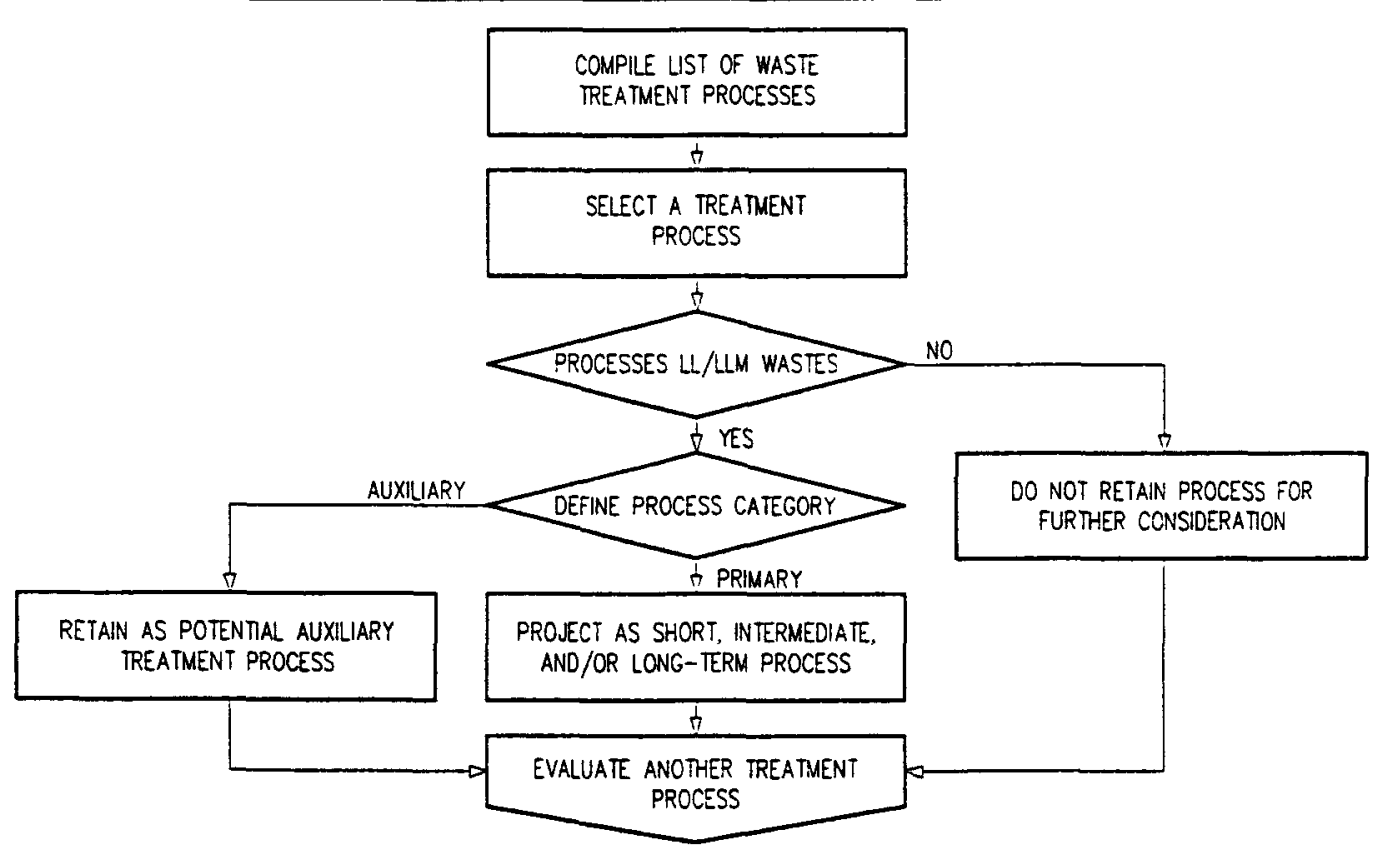


induction-type heater. The fluidized-bed calciner, developed at Idaho National Engineering Laboratory (INEL), uses a kerosene and oxygen mixture. When nitrate slurries are the feed material, the calcine product usually has less than $0.5 \%$ moisture and $5.0 \%$ residual nitrates. ${ }^{1}$

\section{Comments}

Calcining could be used if an oxidized solid material is required for another treatment process. The calcine process would be an auxiliary treatment with no destruction capability. Calcining equipment is commercially available and could meet a short-, intermediatc-, or longterm schedule.

\section{Water Addition}

\section{Process Description}

Water addition would be used when dilution of oils or combustible wastes is required prior to beginning a treatment process. Water addition would require pumps, tanks, agitators and process control instrumentation. In some cases, tank and line heaters may be used to heat the waste streams. An atomizer jet is used in the feed line for waste oils requiring atomizing. Eventually, the added water must be removed, so dewatering technologies should be considered as a later processing step.

\section{Comments}

A water addition process could be used as a pretreatment step when a subsequent process requires slurried solid wastes or diluted organic waste streams. A dewatering process may be required later.

\section{Mixing}

\section{Process Description}

Mixing is used when a treatment process requires the feed to be a homogeneous liquid or slurry. The mixing normally takes place in tanks with agitators. Agitators can be designed to accommodate almost any material with varied shear force requirements. Baffles may also be added to increase slurry mixing. Tanks normally have level and flow-rate instrumentation connected to the pumping system. Mixing can be done at elevated temperatures and pressures.

\section{Comments}

The mixing process would be an auxiliary step following water or chemical additions and could be used for either solid or organic waste streams. A filtering step may be needed later to separate the mixed materials.

\section{Shredding}

\section{Process Description}

Shredding reduces the size or volume of solid material. The size of the feed material, the size limit for material leaving the shredder, and the capacity or throughput required determines the size of the shredding equipment. The shredder design determines the type of material (such as paper or metal) that can be shredded. A method for size classification (screens or cyclones) may be required so that oversized particles exiting the shredder are recycled through the process.

\section{Comments}

Shredding could be an auxiliary step prior to any chemical, thermal, or immobilization process step. It may be necessary to add a size classification step to meet the size requirements for material being fed and discharged from the shredder. Shredding and classification equipment is commercially available to meet a short-, intermediate-, or long-term schedule.

\section{Pelletizing}

\section{Process Description}

Pelletizing agglomerates solid particles into a uniform shape. An agglomeration can be a 
mixture of materials: for example, paper and coal. Solid material is normally shredded or ground prior to pelletizing to produce the desired particle size distribution. The particles are then bound together using binders, pressure, and heat treating. The binder produces a dense material with good compressive strength. Binders are made from various materials including corn syrup, molasses, casein, and hide glue. The pressure is provided by the pelletizing equipment. Generally, controlled-temperature heating of the pelletized product ensures stability during handling of the final product. ${ }^{2}$

\section{Comments}

Pelletizing would be an auxiliary step for combining solid wastes into a uniform shape. The primary is ease of handling the final product. Pelletizing equipment is commercially available and could meet a short-, intermediate-, or longterm schedule.

\section{Dewatering}

\section{Process Description}

Dewatering a waste stream may require several types of equipment or chemicals. The equipment used may include centrifuges, thickeners, dryers, spray evaporators, and lagoons. Centrifuges separate different material types into layers, beginning with the heaviest material at the bottom. The layers are then removed in various ways depending on the design of the centrifuge. Centrifuges can operate at elevated temperatures and pressures.

Thickeners operate in a manner similar to settling tanks, but require rakes, lime, and/or flocculents to separate the feed materials into sludges and clear liquids. The solid material is concentrated, forming the sludge. ${ }^{3}$ Thickeners normally operate at atmospheric pressure, but are capable of operating at ambient or elevated temperatures.

Dryers remove water from solid wastes or sludges by heating the material, causing the water to evaporate. The dried product may be contaminated by fuel, depending on the design of the dryer. Dryers can operate at elevated pressures. $^{4}$

Spray evaporators use equipment such as sprinklers to discharge aqueous waste into the air where solar evaporation occurs. Lagoons use solar evaporation to extract water from aqueous wastes or slurries. Following evaporation, solid wastes or thick slurries are removed with a front end loader. Both processes, spray evaporators and lagoons, operate at ambient temperature and pressure. Chemical dewatering separates the water from other solutions in the waste, so the water or solutions can be removed by decanting.

\section{Comments}

A dewatering process might be used if water has been added prior to a processing step or if dewatering is required prior to a treatment process. Dewatering equipment is commercially available and could meet a short-, intermediate-, or long-term schedule.

\section{Filtration}

\section{$\underline{\text { Process Description }}$}

Filtering may be used for dewatering slurries and clarifying decanted solutions. The equipment may be one of the following types:

1. Continuous vacuum drum filter

2. Continuous vacuum string filter

3. Continuous American disk filter

4. Belt filter

5. Plate and frame filter

6. Vacuum-leaf filter

Each filter has its advantages and disadvantages, and the application must be known when choosing a specific unit. The filter cake (solid material) that collects on the filter may have a moisture content of 7 to $25 \%$, depending on the 
material being processed, the thickness of the filter cake, and the size distribution of the material. In some cases, filtering aids such as diatomaceous earth may be required. All the filters have some capacity for washing the filter cake.

\section{Comments}

A filtering process could be an auxiliary step for any of the chemical, thermal, or immobilization processes. The equipment would be used to dewater slurries created during a treatment process or to clarify solutions before or after a process. Filtering equipment is commercially available and could meet a short-, intermediate-, or long-term time schedule.

\section{THERMAL PROCESSES}

Thermal processes are generally destructive technologies when used for wastes containing organic compounds. Some thermal processes treat wastes containing inorganic constituents; however, these processes generally entrain the constituents in another medium that is easier to manage and considered much less hazardous. Because of the potential for generating off-gases containing particulates, acids, and other undesirable constituents, an off-gas system may be required for most of the thermal processes that follow. Components of an off-gas system may include a scrubber, filter bank, or a combination thereof. The processes evaluated are: rotary kiln incinerator, infrared incinerator, advanced electric reactor, molten salt, glass melter, microwave melter, wet air oxidation, catalyzed wet oxidation, high-temperature wet oxidation, pyrolytic decomposition, high-temperature pyrolysis with oxygen, fast rotary reactor, cyclone incineration, and supercritical water oxidation.

\section{Rotary Kiln Incinerator}

\section{Process Description}

Rotary kilns destroy organic wastes by oxidation. Wastes and auxiliary fuel enter the elevated end of an inclined, refractory-lined, cylindrical kiln. The wastes are oxidized to gases and ash while passing through the kiln. Operating temperatures typically range between 650 and $980{ }^{\circ} \mathrm{C}$.

Residence time may range from several seconds for gases to several hours for solid wastes. Exhaust gases are treated in an afterburner at 760-1,315 ${ }^{\circ} \mathrm{C}$ (Reference 5, pp 2-7 to $2-11$ ).

\section{Comments}

A rotary kiln was retained for consideration as a long-term process. Treating wastes with a rotary kiln could be very expensive because of high capital costs and excessive downtime for maintenance. Also, a significant amount of time may pass before receiving regulatory approval to operate a kiln. Rotary kilns are commercially available but have not been successfully demonstrated for radioactive wastes.

\section{Infrared Incinerator}

\section{Process Description}

Infrared incinerators oxidize organic wastes using infrared heating elements. Wastes pass through a furnace on a woven metal conveyor belt; pans placed on the belt hold liquid wastes. Oxidation of wastes to gases and ash occurs as the wastes pass under the infrared heating elements. Operating temperatures within the primary chamber are $260-1,000^{\circ} \mathrm{C}$, with a residence time for solids of 10-180 minutes. Off-gases pass through a secondary chamber to complete the combustion of remaining organic constituents. Operating temperatures within the secondary chamber are $540-1,260^{\circ} \mathrm{C}$, with a residence of $2-5$ seconds. This system maintains precise control of temperature and residence time. It can also be designed for easy maintenance. A secondary treatment process would be needed to convert the ash to an acceptable form for disposal. ${ }^{6}$

\section{Comments}

An infrared incinerator is an alternative meriting further investigation as a long-term process. The 
equipment is commercially available and it can handle all forms of waste planned for the FBI. However, an infrared incinerator will require time for development (including modifications to process radioactive wastes), construction, and permitting.

\section{Advanced Electric Reactor}

\section{Process Description}

An advanced electric reactor converts wastes to nonhazardous compounds (e.g., carbon, carbon monoxide, and hydrogen) by thermolysis (i.e., pure heating). Destruction of the wastes takes place in an electrically heated, porous-carbon core reactor. The wastes are added at the top of the reactor and are broken down by thermolysis at approximately $2,200{ }^{\circ} \mathrm{C}$ while passing through the reactor. An unusual feature of the process is that thermal energy is transferred to the wastes by means of radiation rather than conduction or convection. Off-gases pass through a secondary chamber to ensure complete combustion of organic substances. This process is limited to liquid wastes atomized to droplets no larger than 1,500 microns and solid wastes no larger than 35 mesh. Sludges cannot be handled by this process. This unit is also known as a hightemperature fluid wall reactor.?

\section{Comments}

The advanced electric reactor was not retained for further consideration because of difficulties meeting waste size restrictions.

\section{Molten Salts}

\section{Process Description}

Wastes are incinerated in molten sodium carbonate. Heat from the process destroys organic constituents. At the same time, the salt layer traps inorganic contaminants while acting as a scrubber for off-gases and particulates. The salt must be continually changed because of contaminant buildup. Other salts may also be formed during the neutralization of acidic offgases. All wastes treated by this process must have low ash and low water content (Reference 8, pp 81-82).

\section{Comments}

The liquid LLM wastes scheduled for destruction in the FBI have a low water content, but the solid wastes are high in ash content. Therefore, the molten salts method was retained as a longterm process for treating liquid wastes only. The equipment for treating hazardous waste is not commercially available.

\section{Glass Melter}

\section{Process Description}

Glass melters process wastes by trapping inorganic and metallic constituents in a glass matrix while destroying the organic constituents. Wastes are first mixed with glass formers and then introduced into the cavity of a glass melter. Glass formers investigated by RFP include borosilicate (boric acid, sand, and lime) and soda-lime (sand, lime, and soda ash). Electrodes protruding into the cavity below the molten waste level pass an electrical current through the waste/glass mixture. Resistance to the current generates heat within the waste/glass mixture. General operating temperatures are $950-1,250^{\circ} \mathrm{C}$, controlled by adjusting the voltage across the electrodes. Excess oxygen is introduced into the chamber, and residence time is controlled to ensure complete destruction of organic contaminants. A glass furnace can process liquids, wet or dry sludges, and combustible materials. The resulting ash is trapped in the glass matrix. When the glass hardens, the waste is in an acceptable form for shipment. Off-gas treatment is required, and sludges formed during the off-gas treatment can be disposed of in the melter. Volume reduction (approximately 10-30\%) and creation of a disposable waste form can be expected from this process. $^{9}$ 


\section{Comments}

Glass melters appear to meet all requirements for an FBI alternative. However, glass melters were retained for intermediate- and long-term consideration because of high capital costs and continued development of the process. Glass melting equipment is commercially available but has not been licensed for radioactive wastes.

\section{Microwave Melter}

\section{Process Description}

Microwave melters are similar to glass melters except for the heating method. Microwave melters can reduce the volume (to $80 \%$ ) of certain wastes, while at the same time forming a solidified, glass-like mass. Wastes, in the form of dried sludges, are introduced into the cavity and melted at $700-1,370{ }^{\circ} \mathrm{C}$. Organic substances, air, and moisture are driven off, and metallic and inorganic substances are trapped in the glass matrix. When the glass is removed from the chamber, the waste is in an appropriate form for shipment and disposal. ${ }^{10}$

\section{Comments}

Continued research and development is required to produce a microwave system generating a plasma capable of destroying organic molecules. At the present time, research is centered on aqueous-based sludges with high amounts of diatomaceous earth. Two years of additional development is estimated for thoroughly evaluating potential uses for microwave melters; therefore, this process has been retained for intermediate- and long-term consideration.

Microwave melters are commercially available but have not been developed for use with radioactive wastes.

\section{Wet Air Oxidation}

\section{Process Description}

Wet air oxidation is the aqueous-phase oxidation of suspended organic substances using elevated temperatures (175-340 ${ }^{\circ} \mathrm{C}$ ) and pressures (20-200 atm). The process is well suited for waste streams that are too dilute to incinerate economically. Typically, aqueous waste streams containing $1-3 \%$ (by volume) organic constituents can be treated with this process. ${ }^{11}$

\section{Comments}

Liquid waste streams planned for the FBI are not diluted. In fact, water is minimized; therefore, this process is not recommended as an alternative to the FBI.

\section{Catalyzed Wet Oxidation}

\section{Process Description}

Catalyzed wet oxidation is similar to the wet air oxidation process, except that a catalyst is added. The process uses nitrate and bromide ions in an acidic solution to catalyze the organic constituents. Other catalysts, such as copper ion, have been used to improve the performance of conventional wet air oxidation processes.

Aqueous waste streams containing up to $5 \%$ (by volume) organic constituents are treated using this process. $^{12}$

\section{Comments}

Catalyzed wet oxidation is still at the experimental phase of development and can treat only very dilute organic streams. Therefore, it is not recommended as an alternative to the FBI.

\section{High-Temperature Wet Oxidation}

\section{Process Description}

High-temperature wet oxidation is similar to the wet air oxidation process, except that this process operates at higher temperatures. Columns of water placed in the ground develop sufficient pressures to produce high temperatures without 
boiling. The process is still in the experimental stages, and the developer is seeking funding to install a system and collect experimental data.

\section{Comments}

High-temperature wet oxidation was not retained for further evaluation. Development has not proceeded far enough to warrant interest. ${ }^{13}$

\section{Pyrolytic Decomposition}

\section{Process Description}

Pyrolytic decomposition is similar in principle to a controlled air reactor because wastes are heated in an oxygen-free atmosphere and subsequently broken down into gases and residues. The gaseous organic compounds enter an oxygen-rich reactor for complete destruction. Ash is collected for later disposal or treatment. Waste heat is passed through a heat exchanger to preheat incoming waste. ${ }^{14}$

\section{Comments}

Pyrolytic decomposition was retained for consideration as an intermediate- or long-term process. There are several systems of this type already operating throughout the United States. One system has received a Resource Conservation and Recovery Act (RCRA) permit, which may make it easier to acquire a permit for a unit at RFP; however, the process has not been tried using radioactive wastes. According to the literature, this process can treat any of the waste forms planned for the FBI.

\section{High-Temperature Pyrolysis With Oxygen}

\section{Process Description}

The high-temperature pyrolysis with oxygen process closely resembles a blast furnace with environmental controls attached. A shaft furnace is charged with nonhazardous waste and heated to operating temperatures before hazardous wastes are introduced. Additional fuel is required to maintain the operating temperatures, (typically $800-1,650^{\circ} \mathrm{C}$ ). Residence time is controlled to ensure complete combustion. Waste gases pass through a scrubber system prior to being released to the atmosphere. Scrubber waste returns to the furnace. ${ }^{15}$

\section{Comments}

The high-temperature pyrolysis with oxygen process is reportedly capable of treating all wastes planned for the FBI; however, it has not been demonstrated using hazardous materials. Therefore, the process has not received a RCRA permit, and additional time is required for testing and permitting. Estimated capital cost is $\$ 25,000,000$. This system appears to require a much larger supply of waste than is available for the FBI. The process has been retained as a long-term process.

\section{Fast Rotary Kiln}

\section{Process Description}

The fast rotary kiln is similar to the rotary kiln incinerator. This process reportedly has better efficiency because the increased rotational speed (to $20 \mathrm{rpm}$ ) produces better heat transfer and combustion. Operating temperature is approximately $870{ }^{\circ} \mathrm{C}$ with a residence time to 30 minutes (for solids). The system is designed to bum both solid and liquid wastes; therefore, it should process all the FBI wastes. An off-gas treatment system would be required before the off-gases could be released to the atmosphere. ${ }^{16}$

\section{Comments}

A fast rotary kiln would be appropriate for wastes scheduled for destruction in the FBI. The equipment is commercially available; however, the system has not received a RCRA permit and could be examined only as a long-term process. 


\section{Cyclone Incinerator}

\section{Process Description}

The cyclone incinerator is a cylindrical-shaped combustion chamber into which a mixture of fuel, waste, and air are introduced tangentially, producing tangential velocity flow that varies inversely with radial position. The resulting high shear provides intense mixing and complete combustion. Temperature range is $870-1,650{ }^{\circ} \mathrm{C}$ with exhaust gases being cleaned of all ash by centrifugal force. Feeds to this system are liquid organic wastes (e.g., oils) only. Additional fuel is required to maintain operating temperatures. ${ }^{17}$

\section{Comments}

Two commercial-size cyclone incinerators are on order, but have not yet received a RCRA permit. This system treats liquid wastes only, and another process is required to treat solid wastes. This process has been retained as an intermediate- or long-term process.

\section{Supercritical Water Oxidation}

\section{Process Description}

Supercritical water oxidation is a process for converting hazardous organic constituents in aqueous wastes to nonhazardous compounds. It can treat waste streams having 1 to $20 \%$ organic constituents. The waste stream, containing organic contaminants, and feed material is pressurized and heated to supercritical conditions (exceeding $647 \mathrm{~K}$ and $22.13 \mathrm{MPa})^{18}$ with recycled reactor reaffinate water. (The critical density of water is $0.326 \mathrm{~g} / \mathrm{cm}^{3}$.)

Next, oxygen in the form of compressed air or liquefied oxygen is added to the reactor. The feed material, water, and oxygen react approximately five seconds in the reactor. ${ }^{19}$ The oxidizing conditions convert carbon to carbon dioxide, hydrogen to water, nitrogen to ammonia and dinitrogen, phosphorus to phosphoric acid, sulfur to sulfuric acid, and halogens to the corresponding halogen acids. Acids, such as $\mathrm{HCl}$, formed during supercritical oxidation can be neutralized with the addition of hydroxides. ${ }^{18}$ Inorganic or chloride salts created during supercritical oxidation are almost totally insoluble in water.

The reactor discharge solution is fed to a cyclone where salts or solid materials are removed. The reactor discharge solution and the gas stream can be expanded through turbines to remove the available energy as power. This provides a cost savings that can be excluded from the cost of operating the unit. Without turbines, cooling and condensation of the heated discharge solution and gas stream must be accomplished using another method.

MODAR, Inc. has patents for above-ground supercritical water oxidation units using the process described. MODAR has operated a 30gal/day pilot plant since 1984 and has begun design work on the first commercial plant. The MODAR unit will require additional development work before processing solid wastes. MODAR has estimated that a waste capacity of 2,500 $\mathrm{gal} / \mathrm{day}$ and a heat release rate of $1,500,000$ $\mathrm{Btu} / \mathrm{hr}$ will result in a processing cost of $\$ 0.8 / \mathrm{gal}$. These values are based on an aqueous waste feed stream with $1,750 \mathrm{Btu} / \mathrm{lb}$ heating value. ${ }^{19}$

Supercritical water oxidation is expected to achieve destruction efficiencies exceeding $99.99 \%$ for all halogenated and nonhalogenated solvent constituents (Reference 20, pp 8-1 to 8-43) with no $\mathrm{NO}_{x}$ generated, and it should produce solvents at the parts-per-billion range in the liquid discharge stream. The supercritical water oxidation process should be able to treat machining wastes, paint wastes, lubricant wastes, PCB-contaminated oil, and waste solvents. ${ }^{18}$ Construction materials for the supercritical reactor are important because corrosive conditions during oxidation may cause limited equipment life.

\section{Comments}

Supercritical water oxidation could process the liquid organic waste streams. However, the plastics and combustibles would require another process. This process cannot meet the short- or intermediate-term time frames because it is in the 
demonstration and pilot-plant phases of development. However, it has significant potential as a long-term solution because of its capability to destroy organic wastes.

This process, along with others described herein, would be operated using high pressures. The wastes have low levels of radioactive constituents, and adequate precautions are required to control the potential for radioactive contamination caused by failure of a pressurized vessel. Therefore, all treatment processes using vessels subjected to high pressures will comply with applicable standards, including the American Society of Mechanical Engineers, Boiler and Pressure Vessel Code, American National Standards Institute, Standard for Steel Pipe Flanges and Flanged Fittings, and the American Society for Nondestructive Testing.

\section{CHEMICAL PROCESSES}

A chemical process alters the chemical structure of contaminants within wastes. Chemical processes are generally intended for liquid wastes with either organic or inorganic contaminants. The contaminants may be made less soluble (e.g., precipitate), converted to nonhazardous compounds (e.g., $\mathrm{H}_{2} \mathrm{O}$ and $\mathrm{CO}_{2}$ ), or converted to a less hazardous form such as removing halogen atoms from halogenated hydrocarbons. The processes evaluated are: aqueous-phase alkaline destruction, acid digestion, dechlorination, precipitation, aqueous-phase alkaline, catalytic dehalogenation, ultraviolet light/peroxide/ozone, and biodegradation.

\section{Aqueous Phase Alkaline Destruction}

\section{Process Description}

The aqueous phase alkaline destruction process converts solid organic material or sludges into oil. The organic material or sludge is digested, in the absence of oxygen, using a mild alkali at temperatures of $250-400^{\circ} \mathrm{C}$ and pressures of 500 $3,000 \mathrm{psi}$. Residence time can range from 0.5 to 5 hours. The product oil can have a heating value to $90 \%$ of that produced by diesel oil. The solid organic material or sludges can be halogenated liquids and granulated solid material, including organic polymers (e.g., cellulose and lignin from paper, rags, and biomass). this process has been tested using Lindane and chloroform achieving near-total destruction and producing no dioxin by-products. This method is currently at the laboratory stage of development for most materials. ${ }^{21}$

The process was developed by Battelle Laboratory. Battelle and the American Fuel and Power Corp. tested the process extensively using a pilot-plant unit. A feed of primary, undigested municipal sewage sludge was converted to usable fuel oil, char, and wastewater. The pilot plant operates at a rate of $30 \mathrm{l} / \mathrm{hr}$, using feed containing $20 \%$ solid material and $5 \%$ anhydrous sodium carbonate. The sludge components are dissolved and recombined into aromatic structures, a gas stream, and biodegradable wastewater. Metals in the feed material are concentrated in the char, while organic solvents remain in the fuel oil. ${ }^{22}$

\section{Comments}

This process might be able to treat the solid wastes and solvents separated from the oil, but produces no benefit in treating the oils. This process is in the initial phases of development and could not meet the short- or intermediateterm time schedule, but it could be a long-term solution.

\section{Catalytic Dehalogenation (Dehydrochlorination)}

\section{Process Description}

Catalytic dehalogenation decontaminates wastes containing halogenated organic solvents by replacing halogen atoms in halogenated compounds with hydrogen atoms. The reaction takes the form:

$$
\mathrm{R}-(\mathrm{X})_{\mathrm{n}}+\mathrm{H}_{2} \stackrel{\text { catalyx }}{\longrightarrow} \mathrm{R}-(\mathrm{H})_{\mathrm{n}}+\mathrm{nHX},
$$

where $\mathrm{R}$ may be an aliphatic or hydrocarbon radical. If chlorine is replaced, the process may be called dehydrochlorination. 
The Gard Division of Chamberlain National has developed a proprietary process for dehalogenation. The process occurs at temperatures of $150-200{ }^{\circ} \mathrm{C}$, pressures of $3-10 \mathrm{~atm}$, with reaction times of 10-20 minutes. Catalysts include platinum, palladium, and rhodium. Potential by-products of the process include solvents with unreacted halogenated compounds, halogen acids, and catalytic materials. Process efficiencies have been very good. One analysis found a $93.5 \%$ reduction in oil for $\mathrm{PCBs}$ with initial concentration of $2,080 \mathrm{ppm}^{23}$

Other investigations have found that temperatures of $671-707^{\circ} \mathrm{F}$, pressures of $30-50$ atm, with catalysts of $61 \%$ nickel on Kieselguher or $10 \%$ palladium in carbon (used for PCBs) were appropriate for dehydrochlorination. ${ }^{24}$

The KTI CHLOROFF process is a dechlorination procedure that is an extension of a widely used lubricant reclamation process called KTI RELUBE. The CHLOROFF process is roughly divided into three phases: Phase 1 is pretreatment, which is primarily particulate filtration. Phase 2 is catalytic hydrodechlorination.

Dechlorination occurs in the presence of hydrogen under pressures of $50-60$ bar at $250-400{ }^{\circ} \mathrm{C}$.

During dechlorination, the chlorine atoms on the organic contaminants are replaced by hydrogen atoms. This step is performed twice in a tricklephase reactor. Phase 3 is distillation of the end products. This process has been successfully demonstrated on lubricants and pesticide production waste streams. ${ }^{25}$

\section{Comments}

Because of the promising nature of the technology, catalytic dehalogenation was retained for further consideration as an auxiliary treatment.

\section{Ultraviolet Light/Peroxide/Ozone Treatment}

\section{Process Description}

The ultraviolet light/peroxide/ozone process uses a strong oxidizing agent, peroxide $\left(\mathrm{H}_{2} \mathrm{O}_{2}\right)$ or ozone $\left(\mathrm{O}_{3}\right)$, in the presence of ultraviolet (UV) light to decontaminate aqueous waste streams containing hazardous organic compounds. The oxidant is added to the wastewater, which is then irradiated with UV light. The UV light converts the $\mathrm{O}_{3}$ and/or $\mathrm{H}_{2} \mathrm{O}_{2}$ to hydroxyl radicals $(\cdot \mathrm{OH})$, which possess a high level of reactivity. Decontamination of the waste occurs when the organic contaminants react with the $\cdot \mathrm{OH}$ radicals to form nonhazardous compounds: carbon dioxide, chlorides, and water. ${ }^{26}$

Efficiency of the process depends on the quantity of oxidants applied to the waste stream, the UV dosage, and the residence time in the UV reactor. The efficiency varies as these parameters vary, but it is possible to meet regulatory standards or remove contaminants to non-detectable levels. Wastewater entering a UV light/peroxide/ozone system generally does not require pretreatment. (The process operates at ambient temperature and atmospheric pressure.) However, filtration may be needed to reduce the suspended solids. Suspended solids limit the amount of light entering the solution, reducing the production of - $\mathrm{OH}$ radicals and consequently reducing overall effectiveness of the treatment.

\section{Comments}

The UV/peroxide/ozone process was not retained as a consideration for destroying concentrated oil wastes. Destruction of the oils would require a substantial dilution (possibly $500-1,000 \mathrm{ppm}$ ) of the oils, and a long reactor residence time. ${ }^{27}$

\section{Electrochemical Removal of Metal Contaminants}

\section{$\underline{\text { Process Description }}$}

Two electrochemical processes were considered for extracting metal ions from solution: electrodialysis and electrowinning.

Electrodialysis is used by the electroplating industry to concentrate metals in process waste streams. ${ }^{28}$ An aqueous waste stream containing metal salts is fed into the center chamber of a three-chamber unit. Semi-permeable membranes 
separate the center chamber from the others. The feed wastes are then subjected to an electrical charge. Anions, mainly sulfates and chlorides, pass through an anion-permeable membrane and collect in the anode chamber. The cations, mainly metals, pass through a cation-permeable membrane and concentrate in the cathode chamber. The deionized water remains in the center chamber, ready for discharge or further treatment. The concentrated anionic and cationic solutions require further processing.

Electrodialysis is used for treating waste streams containing nickel, copper, cyanide, chromic acid, iron, and zinc. The process works best for acidic wastes containing one concentrated metal. Pre-treating the incoming waste stream is important to prevent clogging of the system and fouling and deterioration of the membrane. ${ }^{29}$ Particulate matter, oxidizing agents, iron and manganese $(0.2 \mathrm{mg} /)$, and zinc should be removed prior to treatment. The incoming waste stream may also require slight acidification to prevent precipitation of salts and subsequent fouling of the membranes. Membranes may also be susceptible to attack by organic matter such as volatile organic com-pounds (VOCs). Oils may foul the membranes.

Electrowinning is a process for creating highpurity metal. An acidic solution containing metal ions is electrolyzed, depositing or plating the purified metal on the cathode, while the anode (inert) creates additional acid. ${ }^{30}$ The process operates at atmospheric pressures and ambient or elevated temperatures.

\section{Comments}

Electrodialysis was not retained for further evaluation. The process is not appropriate for treating solid wastes and the potential for fouling membranes when treating oil wastes makes it undesirable. Neither was electrowinning retained for further consideration. It requires that the solution be aqueous, and the process is primarily used for solutions with a high purity of a specific metal.

\section{Biodegradation}

\section{Process Description}

A biological treatment uses microorganisms to degrade hazardous organic compounds to nonhazardous constituents. The microorganisms metabolize the organic compounds to by-products that the organisms use for growth.

Two classes of biological processes are of general interest for treating hazardous wastes: aerobic (with oxygen) and anaerobic (without oxygen). Acrobic processes are the most common form of biological treatment. During this process, oxygen is available or supplied to the organism. The reaction takes the form:

Organics $+\mathrm{O}_{2}$ merobes $\mathrm{CO}_{2}+\mathrm{H}_{2} \mathrm{O}+$ New Cells.

Aerobic processes have a wide range of applications. However, halogenated hydrocarbons are generally considered refractory to aerobic processes. A better approach is an anaerobic system, although research is being conducted to evaluate aerobic processes to degrade these types of hazardous compounds.

Although there are several different biological reactors, the following are representative of the different types (Reference 31, pp 10-10 to 1011).

1. Activated Sludge: Microorganisms are added to an aerated basin containing aqueous wastes. The microbes degrade the hazardous organic constituents into nonhazardous compounds. As degradation proceeds, more biomass is generated, forming a sludge. Some sludge is recycled, but most requires disposal. Pure oxygen activated sludge and extended aeration are variations of the process.

2. Fixed Film Reactor: microorganisms are grown on a substrate (e.g., rock or plastic), forming a slime layer. Decontamination occurs as aqueous wastes pass through the slime. Biological towers are a variation of the process.

3. Rotating Biological Contactor: A disk with a layer of microorganisms rotates through a 
basin filled with contaminated aqueous waste. The organisms degrade the hazardous organic contaminants while in the water and are aerated when exposed to air.

In situ processes have been used for decontaminating soils contaminated by gasoline spills. Microorganisms in the soil degrade the organic contaminants to derive by-products needed for growth. Many organisms are incompatible with the contaminants and die; however, those surviving and able to metabolize the contaminants expand their population. Additional nutrients, oxygen, or microorganisms may be injected into the soil, if needed, to assist in expanding the organism population.

A process similar to in situ treatment is land treatment. Wastes are spread over soil and allowed to dry. The dry material is then mixed into the top 6-18 inches of soil. Following initial mixing, the soil may be periodically stirred to aerate the soil and disperse hydrocarbon molecules. Nutrients (phosphorous and nitrogen) may be added to stimulate growth of the microorganism population, thereby leaving the oils as the limiting factor for population growth. Studies with crude oil, bunker $\mathrm{C}$ fuel oil, and wax raffinate oil show that decomposition rates may be as high as $70 \mathrm{bbl} / \mathrm{acre} / \mathrm{month}$, costing approximately $\$ 7.00$ per barrel. Caution must be exercised during preparation, because storm runoff may carry contaminants away from the site. ${ }^{32}$

\section{Comments}

It is unlikely that a surface biological reactor would be appropriate for decontaminating the oil streams; the oil concentration is high, and the processes are directed toward aqueous streams. Also, biological systems are susceptible to shock loading. If composition of the waste changes quickly, the microorganisms may die.

Land treatment was retained for consideration as a long-term process for treating oil wastes. This technology offers the advantage of being a destructive technology. However, because the wastes are contaminated with low levels of radionuclides, including plutonium, it is likely that acquiring regulatory approval will be difficult. Another consideration is degradation of hazardous materials in the oil, especially chlorinated hydrocarbons. Anaerobic degradation is generally suggested for chlorinated hydrocarbons; however, research shows that aerobic degradation may be feasible for these contaminants. The many concerns associated with land treatment would require substantial laboratory and pilotscale work to ascertain efficiency of the process.

\section{PHYSICAL PROCESSES}

A physical process changes the form of the waste by removing specific contaminants without chemical or thermal destruction of the contaminants. Frequently, decontamination is accomplished by transferring the hazardous constituents from one medium (waste being decontaminated) to another (e.g., carbon or air). Further, once the contaminant substances are transferred to the second medium, it may be possible to collect (if the material has economic value) or destroy the contaminants. Physical treatment is often directed toward aqueous waste streams contaminated with hazardous organic compounds. The processes evaluated are: evaporation, sonification, crystallization, supercritical carbon dioxide extraction, ion exchange, reverse osmosis, solvent extraction, fractional distillation, air stripping, activated carbon adsorption, and steam stripping.

\section{Evaporation}

\section{Process Description}

Thin-film evaporation equipment can recover the organic material in liquid wastes, if the organic material concentration exceeds 6 to $8 \%$. Thinfilm evaporators process liquids with viscosities to 50,000 centipoises/second (cps), depending on the equipment design. The evaporator produces a vapor stream containing the extracted material while leaving the remaining waste as a residue.

With conventional thin-film evaporators, a limiting factor is the need to keep the bottoms (residues created during evaporation) pumpable, for removal from the unit. During solvent recovery (the vapor stream conducts solvents 
away from the waste), the bottoms may require a certain percentage of solvents to remain pumpable, thereby reducing the efficiency of the process. Past work shows that mixing nonvolatile carrier fluids, such as waste oil, with wastes can produce higher recovery efficiencies for organic solvents by eliminating the need for solvents in the bottoms. This technique is currently applied to halogenated solvent contaminated wastes, with $20-90 \%$ recovery efficiency. Recovered organic solvents may require additional processing (for example, dewatering). The bottoms mixture can be processed through incineration, fuel blending, solidification, or dewatering.

Another factor that may limit the effectiveness of thin-film evaporators is the amount of solid material in the wastes. (Agitated thin-film evaporators tolerate higher concentrations of solid material. $)^{33,34}$

\section{Comments}

Evaporation was not retained for further consideration. The process is directed primarily toward recovering organic material from wastes when there is economic justification. This is not the case at RFP. There is no interest in recovering the solvents, and solvent concentrations are much less than 6-8\%. In fact, an additional waste stream (solvents) would be created; and because the solvents would not be completely extracted from the wastes $(20-90 \%$ recovery efficiency), the bottoms would probably require additional processing steps.

\section{Sonification}

\section{Process Description}

Sonification is the use of sound waves to transfer energy through a medium (e.g., air or water) to an object. The sound waves have specific frequency and amplitude values depending on the design of the equipment or process. Sonification is normally associated with equipment such as sonic reactors (covered by U. S. Patents). Sonification has been used successfully during four separate processes: reduction of particle size, agglomeration, leaching, and dewatering.
During the first process, sonification reduced the size of coal particles, releasing ash and other impurities. The second process agglomerated oil and cold particles producing a lower quantity of oil and a higher percentage of solid material in the agglomerated mixture. ${ }^{35}$ In the third sonification process, metals were leached from metal concentrates during diffusion-controlled reactions in a sonic reactor. The sonic reactor is built without an agitator. The last process used sonification to dewater a filter cake, resulting in a drier and more efficiently washed filter cake.

\section{Comments}

Sonification was retained as a potential auxiliary step for either the liquid or solid wastes.

Sonification equipment is available commercially, but would require development for an RFP application.

\section{Crystallization}

\section{Process Description}

Crystallization is the use of ultra-low temperature refrigerants, such as liquid nitrogen, to separate mixed materials. A Japanese corporation uses a cryogenic process to separate fatty components. After freezing, each individual fatty component is separated from the mixture and then melted. The resulting product has a high purity level. ${ }^{36}$ An American corporation uses a crystallization process to freeze one component of a mixture. The frozen component is rinsed to remove contamination and remelted as pure material. ${ }^{37}$

Crystallization was evaluated for application to wastewater treatment, solvent recovery, metal solution recovery, and incinerator enhancement. The equipment is commercially available, but the processes will require additional development beyond the pilot-plant stage. The cost is estimated at 4 to $30 \%$ per gallon of processed material (nonradioactive), including equipment amortization. The higher per-gallon costs are associated with a 1-gpm treatment plant. For a highly automated 10 -gpm treatment plant, capital cost is approximately $\$ 1,000,000 .^{38}$ 


\section{Comments}

A crystallization process would handle liquid wastes only; another process would be required for solid wastes. Because of the current stage of development, this process would be available only as a long-term solution.

\section{Supercritical Carbon Dioxide Extraction}

\section{Process Description}

Supercritical carbon dioxide extraction removes organic constituents from wastes, using the critical form of carbon dioxide as a solvent to extract the organic constituents. The process operates at the critical temperature $\left(31.1{ }^{\circ} \mathrm{C}\right)$ and critical pressure (7.5 $\mathrm{MPa}$ ) of carbon dioxide. These conditions produce the critical density $\left(0.468 \mathrm{~g} / \mathrm{cm}^{3}\right)$ of carbon dioxide. Supercritical carbon dioxide extraction is used to remove hazardous organic compounds from soils, recover oil from sludge, and recover solvents from slurries. These sludge and slurry streams contained at least $70 \mathrm{wt} \%$ water. Because the process is extractive, the hazardous compounds are not destroyed. If destruction of the solvents and treated organic wastes is required (at RFP), additional processing steps are needed. ${ }^{39}$ The carbon dioxide is also recovered for reuse.

Equipment for supercritical carbon dioxide extraction is similar to that used for supercritical water oxidation. However, because of the lower operating temperatures, construction materials for the reactor are not as critical and the process is easier to manage. The supercritical carbon dioxide extraction process is at the pilot-plant stage of development and would require extensive development work for an RFP application.

\section{Comments}

The supercritical carbon dioxide extraction process could separate solvents, which have an economic value, from wastes. This process is more applicable to the liquid waste streams, and another process is required to process solid wastes. Because of the current development stage, this process is only a possible long-term solution.

\section{Ion Exchange}

\section{Process Description}

Ion exchange is a reversible process for extracting ions, primarily metallic, from aqueous wastes. During this process, there is an exchange of ions between the contaminated liquid phase (aqueous waste) and the solid phase (resin), while producing no permanent change to the resin structure. A major application of the technology is removing hardness, calcium, and magnesium ions from water. The following equation gives an example of the water softening process:

$$
2 \mathrm{RNa}^{+}+\mathrm{Ca}^{+2} \Leftrightarrow>\mathrm{R}_{2} \mathrm{Ca}^{+2}+2 \mathrm{Na}^{+}
$$

The exchange material, $\mathrm{R}$, shown in the sodium form, exchanges two sodium ions for one calcium ion, thereby removing calcium ions from hard water. The calcium-loaded resin is then regenerated, using a concentrated sodium chloride solution to retum the resin to the sodium form. The resin is then ready for another operating cycle.

Ion exchange has been used to remove toxic metal cations and anions, including uranium, from water. The regeneration solution may be an acid, a base, or possibly an $\mathrm{NaNO}_{3}$ or $\left(\mathrm{NH}_{4}\right)_{2} \mathrm{CO}_{3}$ solution for removing uranium. ${ }^{40}$ The regeneration solution may require treatment before disposal. If the resin is not regenerated, it may also require treatment prior to disposal. The process operates at ambient temperatures and atmospheric pressure.

\section{Comments}

Ion exchange was not retained for further consideration. The process is directed toward treating aqueous wastes and would not be appropriate for either solid or oil wastes.

\section{Reverse Osmosis}

\section{Process Description}

Reverse osmosis (also called hyperfiltration) is a process for extracting uncontaminated water from water containing dissolved solids. The remaining water contains the same quantity of dissolved 
solids; but because of the reduced volume, the concentration is substantially higher.

A reverse osmosis unit uses a semi-permeable membrane for the separation. Hydrostatic pressure, sufficient to overcome the osmotic pressure of the solutes, is applied to a contaminated solution. Uncontaminated water is forced through the membrane, while concentrating the dissolved solids. (The membrane is impermeable to the solids.) The applied pressure generally exceeds the osmotic pressure by at least $1 \mathrm{MPa}(-145$ psi). The upper limit for applied pressure is approximately $5.5 \mathrm{MPa}(\sim 800 \mathrm{psi})$; therefore, the system is appropriate for solutions with osmotic pressure to $4.5 \mathrm{MPa}(\sim 650 \mathrm{psi}) .^{41}$

Membranes must conform to the following criteria: ${ }^{42}$

1. Permeable to water while restricting the passage of dissolved solids.

2. Thin, but strong enough to withstand the rigors of the process.

3. Nonreactive with contaminants in the water.

4. Malleable enough to mold into shapes with a high surface area to volume ratio.

Auxiliary processes may be required to extend the life and efficiency of a reverse osmosis unit. Oil, grease, and oxidizing agents should be removed, and prechlorination may be necessary to prevent microorganism buildup on the membrane. Filtration may be needed to remove suspended solids, and the $\mathrm{pH}$ of the solution may need adjustment to a range of 4-7.5.

The basic components of a reverse osmosis system are the membrane, membrane support structure, container vessel, and high-pressure pump. Following are three common types of reverse osmosis units. ${ }^{43}$

1. Tubular: This unit provides a large flow channel, thereby reducing the chance of plugging, but has a small surface area to volume ratio, which reduces the system efficiency.

2. Hollow Fiber Membrane: A case filled with thin hollow fibers $(0.004$ inch) is used to treat water. The fibers offer a high surface area to volume ratio, but are subject to plugging. Substantial pretreatment may be necessary.
3. Spiral Wound: Collection material is sandwiched between permeable membranes and then wrapped around a collection tube. The water permeates through the membranes as it flows through the collection material.

The reverse osmosis process may be used for removing dissolved organic and inorganic solids. The estimated volume of resulting concentrate varies between 10 and $25 \%$ of the original influent volume. This concentrate must be further treated. The process has shown good results for high molecular weight organic species as well as charged anions and cations. Favorable results have been demonstrated for aldehydes, ketones, amines, and alcohols. Pilot-scale investigations demonstrated that a $90+\%$ removal is possible for several organic species, including chloroform, 1,1-dichloroethane, 1,2-dichloroethane, 1,1,1-trichloroethane, and trichloroethene. ${ }^{44}$

Rockwell International has evaluated reverse osmosis for removing radionuclides (uranium, plutonium, and americium) from water during pilot-scale investigations. During one investigation, uranium concentrations were reduced from 716 to $4.4 \mathrm{pCi} / \ell$, and plutonium ( $5 \mathrm{pCi} / \ell$ ) and americium $(2 \mathrm{pCi} / \ell)$ concentrations were reduced to less than $1 \mathrm{pCi} / \ell$ each. Water recovery was approximately $98 \%$. Conditions needed for the process include total dissolved solids at less than $1,000 \mathrm{mg} / \ell$, no calcium, and minimum silica. ${ }^{45}$ Another investigation found that reverse osmosis had a 98 to $99+\%$ plutonium rejection rate with efficiency improving as $\mathrm{pH}$ increased (8.5 optimum). Total dissolved solids removal varied between 89 and $94 \% .^{46}$

\section{Comments}

Reverse osmosis was not retained for further consideration. The process is primarily for aqueous wastes and therefore would not be appropriate for the solid or oil LLM wastes.

\section{Solvent Extraction}

\section{Process Description}

A special case of the phase-distribution law states that at a given temperature, the ratio of equilibrium concentrations for a substance in two 
immiscible solvents is a constant. This principle leads to a solvent extraction technique, the transference of various substances from one solvent to another. The process is applicable to solvents containing both metallic and organic substances. The solvents treated during this process are generally aqueous solutions containing the substances to be extracted. The second solvent is usually organic.

Solvent extraction may be performed in a mixersettler, centrifugal contactor, or packed tower. The solvent passes countercurrent to the aqueous stream. After the exchange, the now-contaminated solvent is sent to a regeneration (e.g., distillation, extraction, evaporation chemical reactor) unit to reclaim the solvent. During the exchange, some solvent could remain in the aqueous solution and may require additional treatment (e.g., steam stripping or centrifuge) before disposal.

Extraction of phenols is one application of the process. ${ }^{47}$

Metal removal, using solvent extraction, has been demonstrated in the metals industry. First, the solvent and an aqueous solution containing metals are mixed and allowed to settle in a mixer-settler. Next, the solvent is mixed with a clean aqueous solution, with the metals entering the aqueous solution. The aqueous solution containing the metal ions may be sent to an electrochemical process, such as electrowinning, to collect the metal. These operations take place at ambient temperatures and pressures, and all solutions are recycled.

\section{Comments}

This process was retained as a potential long-term solution for managing oil wastes. Research would be required to determine which solvents would extract the metal and/or organic constituents yet not react with oils.

\section{Fractional Distillation}

\section{Process Description}

Fractional distillation extracts various compounds from a solution. The compound of interest is present in a liquid phase and is extracted using a second gas phase. Usually, the constituent to be removed has relatively low partial pressure in the gas phase; but through continuous distillation, it is eventually removed from the liquid phase. The compound is collected by condensing the vapor or passing it through a suitable collection agent.

Fractional distillation uses evaporation and condensation to separate a feed stream into two or more solutions based on characteristics of various components in the feed. The operation takes place in a column containing packing material or a series of trays. Heat from the trays or column vaporizes the more volatile components in the feed. The vapors rise to the top of the column and are collected in an accumulator. The bottoms, composed of less volatile distillation by-products, are withdrawn with a portion being returned to the column. Feed streams should have minimal suspended or dissolved solids to reduce fouling of the column. Feeds that tend to polymerize should also be avoided. ${ }^{48}$ Earlier work by the Rocky Flats Waste Process Development group showed that carbon tetrachloride $\left(\mathrm{CCl}_{4}\right)$ can be successfully distilled from machine oil, using typical RFP organic mixtures, but the $\mathrm{CCl}_{4}$ is not a candidate for recycle because trichloroethane is removed with the $\mathrm{CCl}_{4}$.

Batch fractionation is a multistage process for separating a solution into different components when additional cost of the process is justified. This process is more tolerant of a higher solids content. Continuous fractionation is appropriate for feed streams with little or no suspended or dissolved solids. Pressure and temperature adjustments may be needed. ${ }^{49}$

\section{Comments}

This process was retained as a potential intermediate- or long-term solution. The oil wastes contain several different organic constituents, and distillation to remove the hazardous constituents may be appropriate.

\section{Air Stripping}

\section{Process Description}

Air stripping is a proven technology for extracting volatile organic compounds (VOCs) from aqueous wastes. The process is so well 
accepted that EPA designated packed tower aeration (air stripping) as a "Best Available Technology" for treating drinking water.

Air stripping is the mass transfer of VOCs from a liquid (water) to a gaseous (air) phase. Transfer continues until equilibrium is established between the two phases. The mass transfer rate is limited by the amount of water surface area exposed to the air, because diffusion occurs at the air-water interface only. Within a column, water flows from top to bottom over the packing material, creating a broad surface area. At the same time, air (several times the volume of water) passes from bottom to top (countercurrent) over the water. The VOCs enter the passing air, which is then emitted to the atmosphere or treated (e.g., vapor-phase carbon) and then emitted. Extraction efficiencies exceeding $99 \%$ are possible. A liquid phase carbon adsorption unit is commonly used as a polishing unit following an air stripper to increase the efficiency of contaminant removal. ${ }^{50}$

Water is processed at ambient temperatures and atmospheric pressure. Minor adjustments may be needed, including filtration to remove solid material and $\mathrm{pH}$ adjustment to increase carbonate solubility.

\section{Comments}

Air stripping was not retained for future consideration. There is no indication that this method has been used for decontaminating oils. Difficulties would likely be encountered because the oil viscosity would tend to inhibit flow through the packing material in a column.

\section{Activated Carbon Adsorption}

\section{Process Description}

Granular activated carbon has proved effective for removing VOCs from aqueous wastes. This process is so effective that EPA designated granular activated carbon adsorption a "Best Available Technology" for removing VOCs from drinking water.
The value of activated carbon is that organic molecules adsorb (adhere) to its surface. The carbon has a high surface area to weight ratio estimated at 500 to $1,500 \mathrm{~m}^{2}$ per gram, ${ }^{51}$ which provides substantial opportunity for organic molecules to collect on the carbon. This is the reason for the effectiveness $(99+\%)$ of activated carbon as a water treatment.

Although there are different forms of adsorption, physical adsorption is of primary interest. Interior to the carbon, the attractive forces (referred to as Van der Waal's forces) are in balance; however, at the surface, the forces are unbalanced. This imbalance results in a net inward attraction, which draws organic molecules to the surface of the carbon. ${ }^{52}$ Adsorption is a preferential process: some compounds are more readily adsorbed than others. For example, granular activated carbon is excellent for trichloroethylene, but should not be used for vinyl chloride.

Carbon continues to adsorb organic molecules until the carbon surface is in equilibrium with the surrounding solution. At this point, the carbon is saturated and will adsorb no more organic material. Saturation is determined by measuring concentration of contaminants in the influent and effluent streams. While the carbon remains unsaturated, the effluent concentrations remain at or below non-detectable or regulatory limits.

Once saturated, one or more contaminant concentrations in the effluent will suddenly increase, eventually attaining the same concentrations as the influent. This sudden rise in effluent concentrations is termed breakthrough. When breakthrough occurs, the spent carbon must be replaced.

Two options are available for spent carbon: disposal or regeneration. If disposal is chosen, the carbon is sent to a repository licensed to accept hazardous wastes. (The carbon is loaded with hazardous organic compounds.) The second option is regeneration. Contaminated carbon is shipped to a regeneration facility where organic compounds are driven off by heating or steam regeneration.

Factors that may affect system efficiency include contact time (the time a volume of water is in contact with carbon), $\mathrm{pH}$ (affecting adsorption of 
different classes of organic compounds), temperature (affecting viscosity), and hydraulic loading (volume of water per cross-sectional area of the carbon). Generally, water is treated at ambient temperature. The only pressure applied is that needed to drive water to or through the carbon. Filtering may be needed if the concentration of suspended solids exceeds $50 \mathrm{ppm}$. (Some systems may accept higher concentrations.) Dissolved inorganic compounds plus oil and grease should be less than $10 \mathrm{ppm}^{53}$

\section{Comments}

The use of activated carbon adsorption was not retained for treating oil wastes. Wastes in the tanks contain more than $90 \%$ oil, which greatly exceeds the recommended $10 \mathrm{ppm}$, and diluting the oil would be impractical.

\section{Steam Stripping}

\section{Process Description}

Steam stripping is a process for removing organic compounds from aqueous solutions. This process is related to both air stripping and fractional distillation.

Heated waste streams are fed into a tower filled with packing material or trays. As the waste flows downward through the tower, steam passes countercurrent to the stream. Organic contaminants that have volatilized exit the wastes and collect in the steam. Subsequent treatment, such as incineration, will be required for the collected contaminant $^{54}$ Steam stripping has been used successfully by industry to remove hydrogen sulfide and ammonia. Further, steam stripping should be effective for removing many chlorinated hydrocarbons, including 1,1,2-trichloroethane, carbon tetrachloride, and 1,2-dichloropropane. Steam stripping may be used to treat solutions with organic concentrations ranging from 100 ppm to $20 \%$.

The literature describes two processes that use steam stripping as a step during reclamation of used oils. The first is a predistillation process. The oil is processed in a steam stripper still for four hours. The process removes $\mathrm{NO}_{\mathbf{x}}$, light oil compounds, and water. The second procedure is a dehalogenation-like process followed by steam stripping. In the first step, oils are subjected to a hydrogen atmosphere, pressures of 50-150 atm, and temperatures of $330-360^{\circ} \mathrm{C}$ within a catalytic reactor. Catalysts used include molybdenumcobalt or tungsten and tungsten-nickel. The second step, steam stripping, removes the byproducts of the first step, including hydrogen sulfide, ammonia, water, and volatile compounds. ${ }^{55}$

\section{Comments}

Steam stripping was retained for further consideration as an auxiliary step. The process could possibly be used as a step during treatment of the waste oils.

\section{IMMOBILIZATION PROCESSES}

Immobilization processes convert wastes to a form that is more easily handled or acceptable for disposal. Current environmental regulations dictate that wastes intended for disposal at a hazardous waste facility contain no free liquids.

Stabilization and solidification are two methods of immobilization. Stabilization alters the solubility or chemical reactivity of the waste. Solidification converts the waste to a solid. (Radioactive wastes may require solidification prior to disposal at a facility licensed to accept radioactive wastes.) Fixation is a term frequently used to refer to the same processes.

This form of treatment is directed toward solid and liquid wastes, soils, and ash. The processes evaluated are: sorption, lime-fly ash pozzolan, pozzolanic-portland cement, thermoplastic encapsulation, macroencapsulation, and specific commercial products. ${ }^{56}$

\section{Sorption}

An adsorbent material is added to wastes to produce a form that is easier to handle. The sorbent may react chemically or physically. Commonly used materials include bottom ash, fly 
ash, and kiln dust from lime and cement manufacture. The pH level may need adjusting depending on the type of sorbent used. When choosing a sorbent, the quantity of product needed to prevent generation of free liquids must be considered, as well as the compatibility between product and the waste or contaminants.

\section{Lime-Fly Ash Pozzolan}

Fly ash or other pozzonlanic material is mixed with the wastes. Next, lime is added. The final mixture is then placed in forms and allowed to harden. Oil, grease, and compounds such as sodium borate, calcium sulfate, and potassium bichromate may adversely affect the strength of the solidified mass by interfering with bonding.

\section{Pozzolanic-Portland Cement}

The strength and chemical characteristics of solidified wastes created by adding portland cement (usually Type I) to the wastes may be improved by adding pozzolanic material to the waste-cement mixture. Oil, grease, and soft fine waste may adversely affect the strength of the solidified mass by interfering with bonding. Acidic materials in the wastes may lead to a breakdown of the concrete after setting.

\section{Thermoplastic Microencapsulation}

Waste is dried, then mixed with a plastic material to form a malleable solid. A commonly used material is asphalt, but other materials are polyethylene, polypropylene, wax, or elemental sulfur. Possible problems include softening of the solid, if solvents or greases are present, and rehydration of sodium sulfate hydrates (water lost during the asphalting process). Asphalt is better than pozzolanic or pozzolanic-portland cement when oxidizing or complexing agents are eliminated from the wastes.

\section{Macroencapsulation}

Macroencapsulation includes sealing wastes in polyethylene-lined drums and applying inert coatings to solidified masses.
Auxiliary steps may include destruction of reactive materials (e.g., acids and oxidizers), volume reduction, binding hazardous compound into the solid structure, and bulking and homogenizing wastes to simplify solidification and stabilization processes.

The following products were evaluated by Rockwell International for solidifying and stabilizing wastes generated at Rocky Flats:

1. Petroset IIß (Fluid Tech, Inc.): This product solidifies most hydrocarbon compounds, but not aqueous wastes (although the wastes may contain some water). The product is readily mixed with wastes by stirring. An activator may be needed to aid solidification of pure oils. The optimum pH range is 5-9. The resulting solid has the consistency of a gel and no free liquids. ${ }^{57}$

2. Envirostone ${ }^{\circledR}$ (United States Gypsum Company): Envirostone emulsifier and water are added to oil to create an oil-water emulsion. Next, Envirostone gypsum cement is added to the mixture, which is then allowed to harden in a drum. Liquids do not seep from the solidified mass. ${ }^{58}$

3. Portland Cement (Type I): Bench-scale tests were performed to test the potential for using portland cement to solidify oils. The results were unsatisfactory because free liquids seeped from the solidified mass. ${ }^{59}$

\section{Comments}

Solidification and stabilization processes have been retained for further consideration as a short, intermediate-, and long-term treatment. These processes were previously proven on Rocky Flats generated wastes and may be used for either the original wastes or (later) for ash or treated wastes.

\section{CONCLUSIONS}

The FBI is expected to be an effective technology for destroying LLM wastes. Therefore, all 
proposed alternative systems must achieve the same objectives as the FBI, including reducing the quantities of LLM wastes stored at RFP and treating LLM wastes that are generated.

Characterization of the LLM waste streams show that each stream has different properties and, consequently, different requirements when identifying appropriate treatment processes. Therefore, because of the limitations inherent in each process, it is unlikely that one method (with possible exception of some form of incineration) will be adequate for treating all LLM wastes generated at RFP. Each of these requirements must be considered during future efforts to define treatment systems for replacing the FBI. This may lead to a systematic study matching individual wastes to specific intermediate- and long-term treatment processes with appropriate attention to various factors, including regulatory requirements. Explanations of the difficulties that may be encountered while defining an adequate treatment system follow:

1. The ideal goal when evaluating waste treatment processes is either destruction or a significant volume reduction. However, many of the processes attack only one problem, such as reducing concentration of hazardous organic or metallic constituents while failing to reduce the volume.

2. Different waste forms require different methods of processing, which complicate the design of a total treatment system. The following factors may affect the design.

- An incineration process appears to be the prime candidate for simultaneous destruction of all forms of LLM wastes. However, alternative incineration processes may produce the same concerns as those for the FBI.

- Processes for treating solid wastes are limited primarily to thermal and fixation.

- Many processes for treating liquid wastes are directed toward decontaminating aqueous solutions (e.g., contaminated wastewater). The liquid LLM wastes are comprised primarily of oils. This presents unique problems that may not be addressed by common liquid waste treatment processes.

3. The overall efficiency of the process may not be sufficient to achieve a specific desired improvement in the quality of the waste. For example, a solidification procedure may not sufficiently reduce the concentration of organic compounds in a leachate (produced by the waste) to comply with the Land Disposal Restrictions for landfilling wastes.

Once one or more treatment systems have been selected as potential alternatives to the FBI, they must be evaluated. Specific criteria were used to evaluate the FBI, and similar criteria should be used to evaluate effectiveness of the prospective treatment systems. Such criteria should include the following:

1. An alternative treatment system must completely substitute for the FBI. In this context, the various unit operations (singularly or in combination) must treat all wastes scheduled for destruction in the FBI.

2. Secondary waste generation must be minimized.

3. Waste volumes must be substantially reduced.

4. The original waste must be converted to a form acceptable to Colorado and/or other states, EPA, and DOE for storage, transport, and disposal.

\section{RECOMMENDATIONS}

The resources required to engineer, purchase, permit, and install a system capable of treating hazardous and LLM wastes are substantial. At the present time, the pressing need is to treat liquid LLM wastes. Specifically, a short-term option is needed to eliminate the oil wastes in two storage tanks because the tanks are filled to capacity. Assuming a rate of LLM oil generation equal to the existing rate, approximately five years of storage will be available once the tanks are emptied. At that time, a permanent solution will be required. For the long-term, it is prudent to consider all hazardous waste streams when evaluating waste treatment technologies. 
TABLE 5. Processes Chosen for Further Evaluations

\begin{tabular}{|c|c|c|c|c|}
\hline Auxiliary & Thermal & Chemical & Physical & Immobilization \\
\hline $\begin{array}{l}\text { Calcining } \\
\text { Water } \\
\text { Addition } \\
\text { Mixing } \\
\text { Shredding } \\
\text { Pelletizing } \\
\text { Dewatering } \\
\text { Filtration }\end{array}$ & $\begin{array}{l}\text { Rotary Kiln Incinerator (L) } \\
\text { Infrared Incinerator (L) } \\
\text { Molten Salts (L) } \\
\text { Glass Melter (L) } \\
\text { Microwave Melter (L) } \\
\text { Pyrolytic Decomposition } \\
\text { (I,L) } \\
\text { High-Temperature } \\
\text { Pyrolysis (L) } \\
\text { Fast Rotary Kiln (L) } \\
\text { Cyclone incinerator (I,L) } \\
\text { Supercritical Water Oxidation (L) }\end{array}$ & $\begin{array}{l}\text { Aqueous Phase Alkaline (L) } \\
\text { Catalytic Dehalogenation (A) } \\
\text { Biodegradation (L) }\end{array}$ & $\begin{array}{l}\text { Sonification (A) } \\
\text { Cryogenics (L) } \\
\text { Supercritical } \mathrm{CO}_{2} \text { Extraction } \\
\quad(\mathrm{L}) \\
\text { Solvent Extraction (L) } \\
\text { Fractional Distillation (I,L) } \\
\text { Steam Stripping (A) }\end{array}$ & $\begin{array}{l}\text { Sorption (S,I,L) } \\
\text { Lime-Fly Ash } \\
\text { Pozzolan (S,I,L) } \\
\text { Pozzolanic- } \\
\text { Portland Cement } \\
\text { (S,I,L) } \\
\text { Thermoplastic } \\
\text { Encapsulation } \\
\text { (S,I,L) } \\
\text { Macroencapsulation } \\
\text { (S,I,L) } \\
\text { Petroset II }{ }^{R}(S, I, L) \\
\text { Envirostone }{ }_{(S, I, L)} \\
\text { Portland Cement } \\
\text { (S,I,L) }\end{array}$ \\
\hline \multicolumn{5}{|c|}{$\begin{array}{l}\text { A. Auxiliary } \\
\text { S. Short-term availability } \\
\text { I. Intermediate-term availability } \\
\text { L. Long-term availability }\end{array}$} \\
\hline
\end{tabular}

Treatment processes that survived the initial screening by possessing some potential for treating LLM wastes were grouped into three categories based on projected availability: short term, intermediate term, and long term. Several processes were retained not as primary processes, but as auxiliary unit operations to improve efficiency of other waste treatment processes. Processes retained for further consideration are shown in Table 5.

The following processes have little potential application for treating LLM wastes at RFP: advanced electric reactors, wet air oxidation, catalyzed wet oxidation, high-temperature wet oxidation, ultraviolet light/peroxide/ozone, electrochemical removal of metal contaminants, evaporation, ion exchange, reverse osmosis, air stripping, and activated carbon adsorption.

During the screen process, it was found that the number of available short-term options for managing LLM wastes, as alternatives to the FBI, is limited. The three short-term options, in order of preference are to:

1. Transport $L L M$ wastes to INEL for incineration. Although, INEL has been granted interim status, a test burn using 200 gallons of RFP LLM wastes will be conducted to ascertain the efficiency of the Waste Experimental Reduction Facility (WERF) for destroying wastes. This is required before the DOE will approve routine shipments of LLM wastes to INEL. In addition to the time required for performing the test burn and analyzing the data, maintenance activities needed to install an off-gas scrubbing system on the WERF are planned for 1989. (The off-gas system is needed because solid wastes contain a higher level of chlorides than liquid wastes.) This may prevent INEL from accepting LLM wastes for destruction until 1990. Until INEL begins operating the WERF, the wastes will continue to be stored temporarily at RFP. (See Option 3 below.)

2. Ship the LLM wastes to the Nevada Test Site (NTS) for landfill disposal. The wastes must be solidified. Solidification of wastes constitutes a treatment process and will require amending the Part $B$ permit already submitted by RFP for regulatory approval. There is no intention of changing the permit until initial approval is received, which is expected in 1989. Approval of the permit in 1989 will also cause the wastes to be subject to requirements of the Land Disposal Restrictions effective November 1988. These regulations ensure that leachates from solidified wastes sent to NTS for disposal do not exceed the specific hazardous constiment concentration limits listed in Table CCWE of 40 CFR Part 268, subpart D. Wastes will 
continue to be stored temporarily at RFP (Option 3 below) until the Part B permit is amended to account for solidification activities.

3. Continue storing LLM wastes at RFP. This will require the acquisition of new tanks to supplement the tanks already filled, if storage of oils is expected to continue for a significant period of time. Currently, liquid LLM wastes are being packaged in drums and stored in cargo containers sitting on temporary storage pads. Additional tanks would eliminate the need to store the oil wastes in this manner, although storing solid wastes in drums will continue. At best, contained storage of LLM wastes at RFP is only a temporary measure.

The FBI is an appropriate technology for processing bumable LLM wastes at RFP. However, with the difficulties encountered in acquiring regulatory approval for operating the incinerator, it may be prudent to consider an altemative treatment system, especially for the long term. Therefore, we recommend initiating a detailed analysis of potential treatment systems incorporating many of the processes discussed herein. This analysis would include evaluating the proposed short-term alternatives as long-term solutions.

\section{REFERENCES}

1. USDOE, Preliminary Evaluation of Alternative Waste Form Solidification Processes, Volume I: Identification of the Processes, PNL-3244, pp A.20 to A.22, A.35, Pacific Northwest Laboratory, Battelle Memorial Institute, Richland, WA, April 1980.

2. G. D. Hackett and G. E. Harris, "Recycle of Waste Paper," YDZ-386, Martin Marietta Energy Systems, Y-12 Plant, Oak Ridge, TN, January 1988.

3. USEPA, Treatability Manual: Volume III. Technologies for Control/Removal of Pollutants, EPA-600/2-82/001a, Section III.4.1, U. S. Environmental Protection Agency, Office of Research and Development, Washington, D.C., January 1983.
4. A. F. Taggart, Handbook of Mineral Dressing, Ores and Industrial Minerals, pp 17-01 to 1713, John Wiley \& Sons, New York, NY, 1945.

5. USEPA, Mobile Treatment Technologies for Superfund Wastes, EPA/540/2-86/003(f), U. S. Environmental Protection Agency, Office of Solid Waste and Emergency Response, Washington, D.C., September 1986.

6. Reference 5, pp 2-20 to 2-23.

7. Reference 5, pp 2-27 to 2-29.

8. H. Freeman, Innovative Thermal Hazardous Organic Waste Treatment Processes, U. S. Environmental Protection Agency, Noyes Publication, Park Ridge, NJ, 1985.

9. Reference 8, pp 44-48.

10. R. D. Petersen and A. J. Johnson, Rockwell International, Rocky Flats Plant, Golden, CO, personal communications, March 1988.

11. Reference 8, pp 12-21.

12. Reference 8, pp 22-24.

13. Reference 8, pp 30-33.

14. Reference 8, pp 70-76.

15. Reference 8, pp 77-80.

16. Reference 8, pp 93-97.

17. Reference 8, pp 98-100.

18. C. K. Rofer, Kinetics Experiments and BenchScale System, Background, Design, and Preliminary Experiments, LA-11106-MS, pp 1-26, Los Alamos National Laboratory, Los Alamos, NM, September 30, 1987.

19. Reference 8, pp 25-29.

20. USEPA, Technical Resource Document: Treatment Technologies for Solvent Containing Wastes, EPA/600/2-86/095, U. S.

Environmental Protection Agency, Hazardous Waste Engineering Research Laboratory, Cincinnati, OH, October 1986. 
21. Reference 8, pp 35-37.

22. Press Release, "Sewage Sludge Turns to Oil With New Process," Mary H. McGregor, BNW 87-46, Battelle Pacific Northwest Laboratories, Richland, WA, September 16, 1987.

23. Reference 8 , pp 38-43.

24. USEPA, Treatment Technology Briefs: Alternatives to Hazardous Waste Landfills, EPA/600/8-86/017, p 11, U. S. Environmental Protection Agency, Hazardous Waste Engineering Research Laboratory, Cincinnati, OH, July 1986.

25. P. F. Van den Oosterkamp et al., KTI, "CHLOROFF, A Non-destructive Dechlorination Process," Environmental Technology: Proceeding of the Second European Conference on Environmental Technology, June 22-26, 1987, pp 275-283, Mantinus Nijhoff Publishers, Dordsecht, The Netherlands, 1987.

26. D. G. Hager and C. E. Smith, "The UVHydrogen Peroxide Process: An Emerging Technology for Groundwater Treatment," presented at HazMat West 85, Long Beach, Califomia, December 3-5, 1985, reprinted paper provided by Waste-Tech Services, Inc., Golden, CO.

27. D. G. Hager, Peroxidation Systems, Inc., Tucson, AZ, personal communications, March 1988.

28. K. F. Cherry, Plating Waste Treatment, pp 128-129, Ann Arbor Science Publishers, Inc., Ann Arbor, MI, 1982.

29. USEPA, Treatability Manual: Volume III. Technologies for Control/Removal of Pollutants, EPA/600/2-82/001c, Section III.3.1.7, U. S. Environmental Protection Agency, Office of Research and Development, Washington, D.C., September 1981.

30. R. D. Pehlke, Unit Processes of Extractive Metallurgy, pp 224-225, American Elsevier Publishing Company, Inc., New York, NY, 1973.
31. USEPA, Handbook: Remedial Action of Waste Disposal Sites (Revised), EPA/625/6$85 / 006$, U. S. Environmental Protection Agency, Hazardous Waste Engineering Research Laboratory, Cincinnati, $\mathrm{OH}$, October 1985.

32. L. Y. Hess, Reprocessing and Disposal of Waste Petroleum Oils, pp 259-313, Noyes Data Corporation, Park Ridge, NJ, 1979.

33. Reference 20 , pp $7-48$ to $7-86$.

34. USEPA, Project Summary: Technical Resource Document Treatment Technologies for Solvent Containing Wastes, EPA/600/S286-095, pp 1-9, Hazardous Waste Research Laboratory, Cincinnati, OH, February 1987.

35. U. S. Patent Number $4,326,855$, Issued to E. C. Cottell, April 27, 1982.

36. U. K. Patent Application, GB 2,069,520 A, submitted by Nippon Oil and Fats Co., Ltd.

37. J. A. Heist, "Freeze Crystallization," Chemical Engineering, pp 72-82, May 7, 1979.

38. J. A. Heist and P. J. Wrobel, "Freeze Crystallization as a Hazardous Waste Treatment Technology," presented at AIChE 1987 Annual Meeting, New York, NY, November 16, 1987, copy of paper provided by Heist Engineering Corp.

39. USEPA, Project Summary: Near Critical $\mathrm{CO}_{2}$ Extraction of Hazardous Organics From Acrylonitrile, Pesticide, and Steel Mill Wastes, EPA/600/S2-87/005, pp 1-3, U. S. Environmental Protection Agency, Hazardous Waste Engineering Research Laboratory, Cincinnati, OH, May 1987.

40. C. H. Delegard et al., "Characterization and Anion Exchange Removal of Uranium From Hanford Ground Water," Waste Management '86, Proceedings of the Symposium on Waste Management, Tucson, Arizona, March 2-6, 1986, Volume 1, pp 545-550, copyright 1986, Arizona Board of Regents.

41. R. W. Rousseau, (Ed), Handbook of Separation Process Technology, p 836, John Wiley \& Sons, New York, NY, 1987. 
42. H. K. Lonsdale and H. E. Podall (Ed), Reverse Osmosis Membrane Research, p 2, Plenum Press, New York, NY, 1972.

43. Reference 31 , pp $10-40$ to $10-42$.

44. Reference 31 , pp 10-40 to $10-41$.

45. C. E. Plock and T. N. Travis, Purification and Decontamination of a Caustic Water by Reverse Osmosis, RFP-3103, p 2, Rockwell International, Rocky Flats Plant, Golden, CO, July 1981.

46. C. E. Plock and T. N. Travis, Plutonium Decontamination Studies Using Reverse Osmosis, RFP-3005, p 3, Rockwell International, Rocky Flats Plant, Golden, CO, June 1980.

47. G. W. Dawson and B. W. Mercer, Hazardous Waste Management, pp 352-354, John Wiley \& Sons, New York, NY, 1986.

48. J. B. Berkowitz et al., Unit Operations for Treatment of Hazardous Industrial Wastes, pp 373-378, Noyes Data Corporation, Park Ridge, NJ, 1978.

49. Reference 20 , pp 7-3 to 7-15.

50. USEPA, Aeration to Remove Organic Compounds From Ground Water, EPA/600/ 2-86/024, pp 1-56, U. S. Environmental Protection Ágency, Cincinnati, OH, March 1984.

51. S. D. Faust and O. M. Aly, Chemistry of Water Treatment, p 188, Butterworth Publishers, Woburn, MA, 1983.
52.J. W. Hassler, Purification With Activated Carbon: Industrial,Commercial, Environmental, pp 206-212, Chemical Publishing Co., Inc., New York, NY, 1974.

53. Reference 31 , pp 10-4 to 10-7.

54. J. B. Berkowitz et al., Unit Operations for Treatment of Hazardous Industrial Wastes, pp 881-897, Noyes Data Corporation, Park Ridge, NJ, 1978.

55. L. Y. Hess, Reprocessing and Disposal of Waste Petroleum Oils, pp 66, 70, Noyes Data Corporation, Park Ridge, NJ, 1979.

56. USEPA, Handbook for Stabilization' Solidification of Hazardous Wastes, EPA/540/2-86/001, pp 2-1 to 2-24, U. S. Environmental Protection Agency, Hazardous Waste Engineering Research Laboratory, Cincinnati, OH, June 1986.

57. Fluid Tech, Inc., "Solidification Procedures for Radioactive Liquids," Fluid Tech Manual 002, pp 1-6. (This document has been superseded by "Process Control Program for Solidifying Radioactive Waste Using Fluid Tech Solidification Media," Fluid Tech Manual .001), Fluid Tech, Inc., Las Vegas, NV.

58. R. D. Petersen, Organic and Sludge Immobilization System, RFP-4095, pp 1-13, Rockwell International, Rocky Flats Plant, Golden, CO, July 1987.

59. R. D. Petersen, Rockwell International, Rocky Flats Plant, Golden, CO, personal communications, March 1988. 